\title{
Polyamine Action under Metal/Metalloid Stress: Regulation of Biosynthesis, Metabolism, and Molecular Interactions
}

\author{
Mirza Hasanuzzaman ${ }^{1, *}$, Haifa Abdulaziz S. Alhaithloul ${ }^{2}$, Khursheda Parvin ${ }^{3,4}$, \\ M.H.M. Borhannuddin Bhuyan ${ }^{3,5}{ }^{(0)}$, Mohsin Tanveer $\left.{ }^{6}{ }^{(}\right)$, Sayed Mohammad Mohsin ${ }^{3,7}{ }^{(0}$, \\ Kamrun Nahar ${ }^{8}$, Mona H. Soliman 9,10, Jubayer Al Mahmud ${ }^{11}$ and Masayuki Fujita ${ }^{3}$ \\ 1 Department of Agronomy, Faculty of Agriculture, Sher-e-Bangla Agricultural University, \\ Dhaka 1207, Bangladesh \\ 2 Biology Department, College of Science, Jouf University, Sakaka 2014, Saudi Arabia \\ 3 Laboratory of Plant Stress Response, Department of Applied Biological Sciences, Faculty of Agriculture, \\ Kagawa University, Kagawa 761-0795, Japan \\ 4 Department of Horticulture, Faculty of Agriculture, Sher-e-Bangla Agricultural University, \\ Dhaka 1207, Bangladesh \\ 5 Citrus Research Station, Bangladesh Agricultural Research Institute, Jaintapur, Sylhet 3156, Bangladesh \\ 6 Stress Physiology Research Group, School of Land and Food, University of Tasmania, 7005 Hobart, Australia \\ 7 Department of Plant Pathology, Faculty of Agriculture, Sher-e-Bangla Agricultural University, \\ Dhaka 1207, Bangladesh \\ 8 Department of Agricultural Botany, Faculty of Agriculture, Sher-e-Bangla Agricultural University, \\ Dhaka 1207, Bangladesh \\ 9 Biology Department, Faculty of Science Yanbu, Taibah University, Al-Sharm, Yanbu El-Bahr, Yanbu 46429, \\ Saudi Arabia \\ 10 Department of Botany and Microbiology, Faculty of Science, Cairo University, Giza 12613, Egypt \\ 11 Department of Agroforestry and Environmental Science, Faculty of Agriculture, \\ Sher-e-Bangla Agricultural University, Dhaka 1207, Bangladesh \\ * Correspondence: mhzsauag@yahoo.com; Tel: +880-1716-587711
}

Received: 11 June 2019; Accepted: 26 June 2019; Published: 30 June 2019

\begin{abstract}
Polyamines (PAs) are found in all living organisms and serve many vital physiological processes. In plants, PAs are ubiquitous in plant growth, physiology, reproduction, and yield. In the last decades, PAs have been studied widely for exploring their function in conferring abiotic stresses (salt, drought, and metal/metalloid toxicity) tolerance. The role of PAs in enhancing antioxidant defense mechanism and subsequent oxidative stress tolerance in plants is well-evident. However, the enzymatic regulation in PAs biosynthesis and metabolism is still under research and widely variable under various stresses and plant types. Recently, exogenous use of PAs, such as putrescine, spermidine, and spermine, was found to play a vital role in enhancing stress tolerance traits in plants. Polyamines also interact with other molecules like phytohormones, nitric oxides, trace elements, and other signaling molecules to providing coordinating actions towards stress tolerance. Due to the rapid industrialization metal/metalloid(s) contamination in the soil and subsequent uptake and toxicity in plants causes the most significant yield loss in cultivated plants, which also hamper food security. Finding the ways in enhancing tolerance and remediation mechanism is one of the critical tasks for plant biologists. In this review, we will focus the recent update on the roles of PAs in conferring metal/metalloid(s) tolerance in plants.
\end{abstract}

Keywords: Abiotic stress; toxic metal/metalloid(s); amino acids; stress signaling; reactive oxygen species; phytohormones 


\section{Introduction}

Polyamines (PAs) are ubiquitous, water-soluble polycations. They play a vital role in regulating plant physiology and development, as well as stress management [1,2] and newly invented plant biostimulant [3]. In all living cells, the chief PAs are found as diamine putrescine (Put), triamine spermidine (Spd), and tetramine spermine (Spm). They are positively charged and can bind to opposite charged molecules like DNA, RNA, adenosine triphosphate (ATP), proteins, and phospholipids [4]. Polyamines are also involved in regulatory processes, for example, plant growth, the division of the cell, cell differentiation, flowering, embryo development, senescence immunity, replication of DNA, gene regulation and nucleic acid synthesis [3,4]. In addition, PAs can scavenge the reactive oxygen species (ROS) [5] and play vital roles in regulating the plant defense response to diverse metal/metalloid(s) toxicity $[1,6]$.

Metal/metalloid(s) contaminations of soils are considerably increased due to the different activities of human. For example, agricultural and industrial activities discharge a huge amount of toxic waste, therefore metal/metalloid(s) concentration increasing day by day [5]. For plant growth and productivity metal/metalloid(s) are very harmful, because they can induce toxicity in plant cells, thus can be carcinogenic for human if entered into the food web via plant. In addition, metals/metalloid(s) bind with proteins, which contain sulfhydryl groups, and therefore inhibit the activities of enzymes or alter protein structure. Under metal/metalloid(s) stress the toxic ions stimulate the formation of ROS in plants, hence, create oxidative stress by oxidation of macromolecules like protein, lipids, and DNA [7]. Several reports suggested that excess metal/metalloid(s) can be an obstacle with the metabolism of PAs [6,8]. Groppa et al. [6] reported that the metabolisms of PAs are influenced by the application of $\mathrm{Cd}^{2+}$ or $\mathrm{Cu}^{2+}$ notably in wheat or sunflower leaf. In a recent study, Tajti et al. [9] reported that PAs pretreatment could accelerate metal chelation, maintain hormonal balance, enhance an antioxidant defense, and conferred cadmium (Cd) tolerance in wheat.

The exogenous application of PAs regulates the antioxidative mechanisms in plants under metal/metalloid(s) stress to mitigate the overproduction of ROS [8]. Under Cd stress, the exogenous application of Put and/or sodium nitroprusside (SNP, NO donor) scavenged ROS by improving the activity of enzymes (superoxide dismutase, SOD; catalase, CAT; ascorbate peroxidase, APX; monodehydroascorbate reductase, MDHAR; dehydroascorbate reductase, DHAR; glutathione reductase, GR; glutathione $S$-transferase, GST; and glutathione peroxidase, GPX) and nonenzymatic antioxidants (ascorbate, AsA and glutathione, GSH) [1]. The exogenous application of Spd improved $\mathrm{Cd}$ tolerance in Boehmeria nivea L. plant [10]. Rady and Hemida [11] found that the seed priming with Spm or Spd enhanced the Cd tolerance in wheat seedlings. Taie et al. [12] also reported that seed soaking or foliar application of Spm, Spd or Put considerably improved wheat plant growth and yield under $\mathrm{Cd}$ and $\mathrm{Pb}$ stress by increasing tolerance mechanisms. Benavides et al. [5] investigated the effect of $\mathrm{Cd}$ and $\mathrm{Cu}$ on wheat and sunflower plants and found that membrane fluidity altered in plant leaves and roots during germination and seedling stage, but pre-treated plants with PAs avoided that alteration. Therefore, PAs can enhance the tolerance in plants to sustain under metal/metalloid(s) stress condition. Hence, in this review, we have summarized the current knowledge concerning PAs (biosynthesis, metabolism, and molecular interaction) in the plant under metal/metalloid(s) stress. Thus, the objectives of this review to explain the possible roles of PAs improving plant tolerance in relation to antioxidant defense, metal chelation and interaction with other plant molecules under metal/metalloid(s) stress.

\section{Polyamines Biosynthesis and Metabolism}

In plants, briefly, PAs biosynthesis starts with the decarboxylation of either L-arginine (Arg) directly (by arginine decarboxylase, ADC) or from ortinine (by ortinine decarboxylase: ODC) indirectly (Figure 1). The ADC pathway directly produced Put by the chronological action of three enzymes; ADC, agmatine iminohydrolase (AIH), and N-carbamoylputrescine amidohydrolase (CPA), whereas in the ODC pathway, Arg first converts into ornithine by the action of arginase and then ornithine converts 
into Put. Production of orthinine from Arg depends on arginase enzyme activity. After carboxylation steps, the high molecular weight of PAs; Spd and Spm are produced from Put by the sequential addition of aminopropyl groups to Put and Spd and by the action of Spd synthase (SPDS) and Spm synthase (SPMS) enzymes, respectively. Moreover, decarboxylated S-adenosylmethionine (dcSAM) further regulates the activity of SPDS and SPMS to produce Spd and Spm. On the contrary, dcSAM is generated by the decarboxylation of $S$-adenosylmethionine (SAM). Besides, SAM also acts as a precursor of ethylene (ET) production and converts into ET by 1-aminocyclopropane-1-carboxylic-acid synthase (ACS) and oxidase enzyme. Besides catabolism of Put and Spd yields $\gamma$-aminobutyric acid (GABA) via pyrroline. Yet, GABA from this step converts into succinate, which further enters in the TCA cycle (Figure 1).

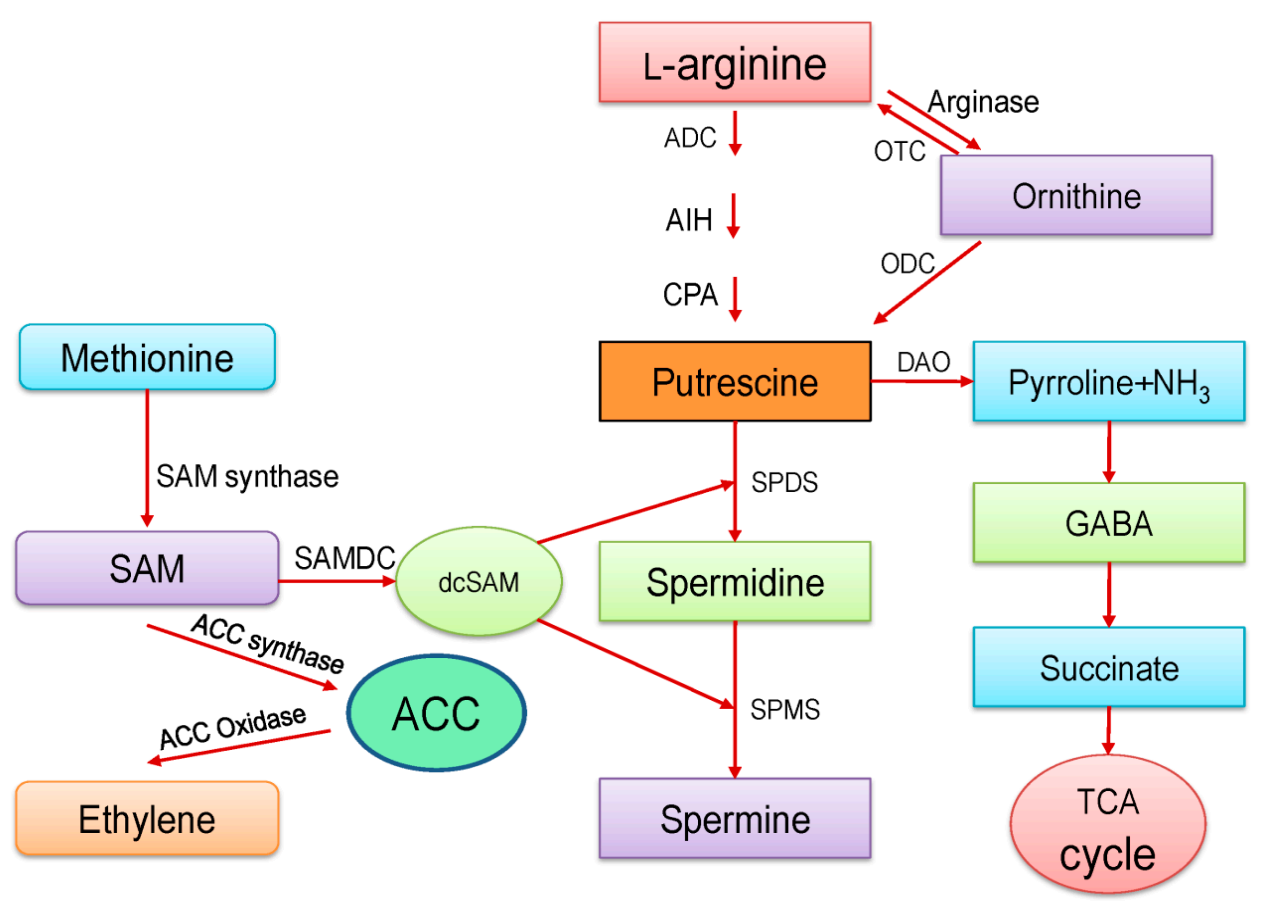

Figure 1. Biosynthesis pathway of polyamines in plants. ADC: arginine decarboxylase; AIH: agmatine iminohydrolase; CPA: N-carbamoylputrescine amidohydrolase; SPDS: spermidine synthase; SPMS: spermine synthase; OTC: ornithine transcarbamoylase; ODC: ornithine decarboxylase; DAO: diamine oxidase; GABA: $\gamma$-aminobutyric acid; SAM: $S$-adenosylmethionine; SAMDC: S-adenosylmethionine decarboxylase; dcSAM: decarboxylated S-adenosylmethionine; ACC synthase: 1-aminocyclopropane-1-carboxylic-acid synthase. Arrows represent the synthesis/conversion.

In different plant species, genes for PAs biosynthesis enzymes have been identified, characterized, and cloned; however, genes encoding sequences for all the above-mentioned enzymatic activities, with the exception of ODC, have only been characterized in Arabidopsis [13]. In Arabidopsis, no ODC activity has been detected so far [14], while two genes for ADC activity (ADC1 and ADC2) and one gene for AIH and one gene for CPA have been identified. According to Alcázar et al. [15], to promote Put accumulation in Arabidopsis the overexpression of homologous ADC2 is sufficient, which suggests that for Put biosynthesis ADC is the limiting step in plants. There are two genes for SPDS (SPDS 1 and SPDS 2), two genes for SPMS (SPS and ACL5) and four genes for SAM decarboxylation (SAMDC1, $S A M D C 2, S A M D C 3$, and $S A M D C 4$ ) have been identified and characterized to examine their role in PAs biosynthesis [16-18]. It was reported that PAs produced from different pathways appeared to have a differential role in plant development. For example, PAs produced via ODC pathway play a role in floral development, while PAs generated via ADC pathway involved in vegetative development [19]. Moreover, it has also been suggested that ODC is related to the regulation of cell division/proliferation, while ADC involved in the stressed tissue and/or extension of the cell [19]. 
Under metal/metalloid(s) stress conditions, PAs accumulation increased by the stimulation of the different steps involved in the PAs biosynthesis process, not by triggering high molecular weight PAs, i.e., Spd or Spm [20]. For instance, under Cd stress, Kuthanová et al. [21] showed increased PAs accumulation mainly due to the high Put accumulation and diamine oxidase (DAO) activity. However, Choudhary and Singh [22] did not find any effects of Cd stress on DAO, despite high PAs accumulation in mung bean. In another study, Groppa et al. [6] showed that high PAs accumulation under Cd stress was due to high ADC and ODC activity in wheat while under Cu stress; only ODC was noted as the main enzyme involved in the higher Put synthesis. Similarly, in maize under $\mathrm{Pb}$ stress, a higher concentration of total PAs has been noted as compared with control, and this was associated with the higher Put synthesis.

\section{Polyamine-Induced Metal/Metalloids Tolerance in Plants}

No plants want to die, and thus try to survive under stress by modulating self-defense mechanisms. As part of this, plants often endogenously synthesize PAs. In previous sections, we stated that PAs retrieve abiotic stresses including metal/metalloid(s). In this section, we will discuss how PAs induce metal/metalloid(s) stress in plants. As sessile organism plants have to survive to tolerate the stress. Therefore, plants have evolved some protective mechanisms against metal/metalloid(s)-induced stresses, such as elimination, metal chelation, and compartmentalization [1] (Table 1; Figure 2). Antioxidant defense system present in a plant cell is very efficient, through which plants cope with metal-induced oxidative stress. Polyamines have an intimate relationship with this antioxidant defense. Plant synthesizes PAs endogenously, which further enhanced antioxidant defense mechanisms, including energizing antioxidants, ROS scavenging, metal chelation, and membrane stability $[1,23]$. Upon stress, PAs work as signaling molecules and consequently regulates ion homeostasis and control ion transportation through interacting with ion channels [24]. Thus, PAs play not only vital roles in normal plant developmental and physiological processes but also have active participation in abiotic stress tolerance [25]. Therefore, stress affected plants alleviate the adverse effect of stress through the expression of PAs biosynthetic genes as well as improving PAs biosynthesis [26].

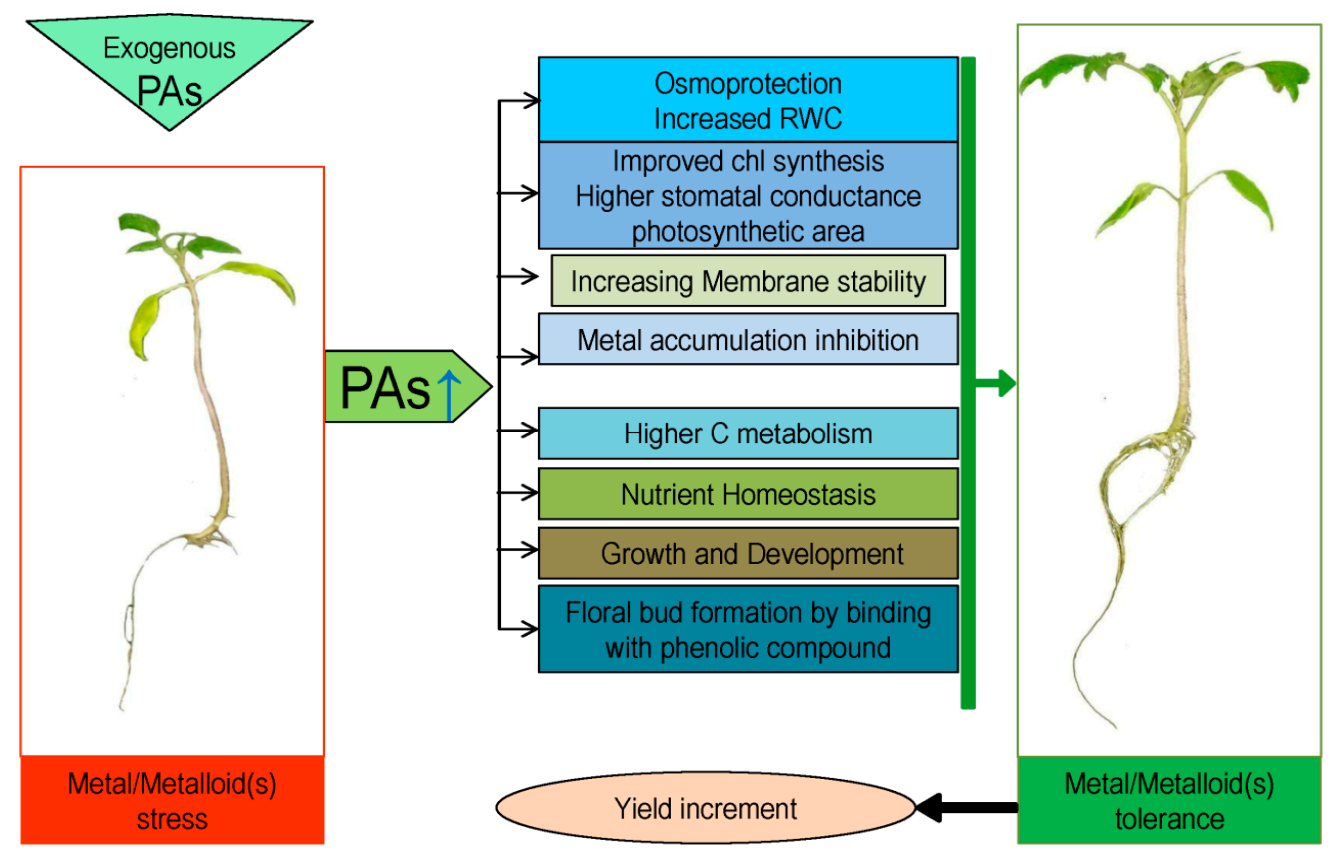

Figure 2. Metal/metalloid(s) stress tolerance by polyamines (PAs). Blue arrow represents the upregulation of PAs accumulation, black arrows represent the enhancement and green arrow represent the tolerance. 
Table 1. Polyamine-induced metal/metalloid(s) tolerance in different plant species.

\begin{tabular}{|c|c|c|c|c|c|}
\hline Plant Species & Metal(s) Exposed & $\begin{array}{c}\text { Changes in } \\
\text { Endogenous PAs } \\
\text { Level }\end{array}$ & Exogenous PAs Used & Tolerance & References \\
\hline Triticum aestivum $\mathrm{L}$. & $1 \mathrm{mM} \mathrm{CdCl}_{2}$ for $5-15 \mathrm{~d}$ & - & $\begin{array}{l}0.1 \mathrm{mM} \text { Put, Spd or Spm } \\
\text { pretreatment for } 5 \text { and } 10 \mathrm{~d}\end{array}$ & $\begin{array}{ll} & \text { Lowered Cd-induced dehydration } \\
\text { - } & \text { Increased chlorophyll content } \\
\text { - } \quad \text { Resfirmed better growth when pretreated for } 10 \text { days } \\
\end{array}$ & Benavides et al. [5] \\
\hline T. aestivum & $2 \mathrm{mMCd}$ as $\mathrm{CdCl}_{2}$ & - & $\begin{array}{l}0.25 \mathrm{mM} \mathrm{Spm}, 0.50 \mathrm{mM} \text { Spd, and } \\
1 \mathrm{mM} \text { Put as seed priming or as a } \\
\text { foliar spray at 20, 40, and } 60 \text { DAS }\end{array}$ & $\begin{array}{l}\text { - Increased plant growth and grain yield } \\
\text { - Decreased Cd accumulation in the root, shoot, and leaf }\end{array}$ & Taie et al. [12] \\
\hline T. aestivum & $2 \mathrm{mM}$ as $\mathrm{PbCl}_{2}$ for $45 \mathrm{~d}$ & - & $\begin{array}{l}0.25 \mathrm{mM} \mathrm{Spm}, 0.50 \mathrm{mM} \text { Spd, and } \\
1 \mathrm{mM} \text { Put as seed priming or as a } \\
\text { foliar spray at } 20,40 \text {, and } 60 \mathrm{DAS}\end{array}$ & $\begin{array}{ll}\text { - Increased plant growth and biomass accumulation } \\
\text { - Enhanced grain yield }\end{array}$ & Taie et al. [12] \\
\hline T. aestivum & $2 \mathrm{mM} \mathrm{CdCl}_{2}$ for $58 \mathrm{~d}$ & - & $\begin{array}{l}0.25 \mathrm{mM} \mathrm{Spm}, 0.50 \mathrm{mM} \text { Spd, } \\
\text { or } 1.0 \mathrm{mM} \text { put as seed priming } \\
\text { and later foliar spraying }\end{array}$ & 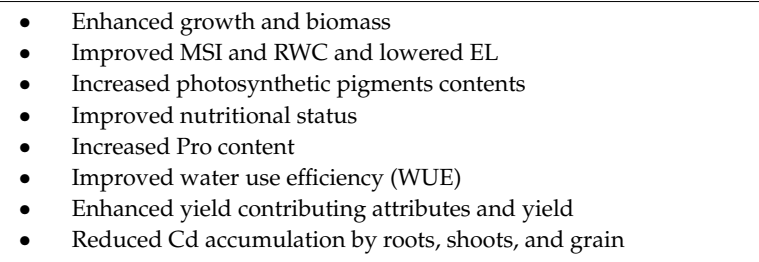 & Rady et al. [28] \\
\hline T. aestivum & $1 \mathrm{mM} \mathrm{CuCl}_{2}$ for $5-15 \mathrm{~d}$ & - & $\begin{array}{l}0.1 \mathrm{mM} \text { Put, Spd, or Spm } \\
\text { pretreatment for } 5 \text { and } 10 \mathrm{~d}\end{array}$ & $\begin{array}{l}\text { - Improved growth under Cu-stress, which was better after } 10 \text { days } \\
\text { of pretreatment. } \\
\text { Put stimulated chlorophyll content and controlled membrane } \\
\text { damage under Cu stress }\end{array}$ & Benavides et al. [5] \\
\hline T. aestivum & $1 \mathrm{mMCd}$ as $\mathrm{CdCl}_{2}$ & $\begin{array}{l}\text { Increased PAs } \\
\text { content }\end{array}$ & $\begin{array}{l}2 \mathrm{mM} \text { Spd or } 2 \mathrm{mM} \text { Spm as a seed } \\
\text { treatment for } 6 \mathrm{~h}\end{array}$ & $\begin{array}{ll} & \text { Increased growth and biomass } \\
\text { - Increased RWC, while decrease Pro content Decrease electrolyte } \\
\text { leakage (EL) and increase membrane stability index (MSI) } \\
\text { - Increased protein and, starch content } \\
\end{array}$ & Rady and Hemida [11] \\
\hline T. aestivum & $30 \mu \mathrm{M} \mathrm{AlCl} l_{3}$ & Increased Spd & Put, $2 \mathrm{mM}$ & $\begin{array}{l}\text { - Increased Spd content } \\
\text { - } \quad \text { Decrease cell death in both genotypes }\end{array}$ & Yu et al. [29] \\
\hline T. aestivum & $2 \mathrm{mMCd}$ & $\begin{array}{l}\text { Increased Spm and } \\
\text { Spd content }\end{array}$ & - & - Increased Pro content & Howladar et al. [30] \\
\hline T. aestivum & $2.0 \mathrm{mM} \mathrm{Pb}^{2+}$ & - & $\begin{array}{l}0.25 \mathrm{mM} \text { Spm, } 0.50 \mathrm{mM} \text { Spd or } \\
1.0 \mathrm{mM} \text { Put as seed treatment }\end{array}$ & $\begin{array}{l}\text { - Improved plant height, leaf number, and fresh biomass } \\
\text { - } \\
\text { - } \quad \text { Excreased total Chl and car content with higher RWC yield contributing characters and produced a } \\
\text { higher yield } \\
\text { - } \\
\text { Enhanced plant macronutrient }(\mathrm{N}, \mathrm{K} \text {, and } \mathrm{P}) \text { content }\end{array}$ & Rady et al. [31] \\
\hline
\end{tabular}


Table 1. Cont.

\begin{tabular}{|c|c|c|c|c|c|}
\hline Plant Species & Metal(s) Exposed & $\begin{array}{l}\text { Changes in } \\
\text { Endogenous PAs } \\
\text { Level }\end{array}$ & Exogenous PAs Used & Tolerance & References \\
\hline Helianthus annuus $\mathrm{L}$. & $1 \mathrm{mMCdCl}_{2}$ for $5-15 \mathrm{~d}$ & $\begin{array}{l}\text { Increased Put, Spd, } \\
\text { and Spm content }\end{array}$ & $\begin{array}{l}0.1 \mathrm{mM} \text { Put, Spd, or Spm } \\
\text { pretreatment for } 5 \text { and } 10 \mathrm{~d}\end{array}$ & $\begin{array}{l}\text { - Put enhanced chlorophyll content } \\
\text { - Pretreatment for } 10 \text { days showed better tolerance } \\
\text { Inhibited the negative effect of } \mathrm{Cd} \text { on membrane } \\
\text { biophysical properties }\end{array}$ & Benavides et al. [5] \\
\hline H. аппииs & $1 \mathrm{mMCuCl}_{2}$ for $5-15 \mathrm{~d}$ & $\begin{array}{l}\text { Increased Put, Spd, } \\
\text { and Spm content }\end{array}$ & $\begin{array}{l}0.1 \mathrm{mM} \text { Put, Spd, or Spm } \\
\text { pretreatment for } 5 \text { and } 10 \mathrm{~d}\end{array}$ & $\begin{array}{l}\text { - } \quad \text { Put and Spm stimulated chlorophyll content in } \\
\text { - } \quad 10 \text { days of pretreatment showed better plant growth } \\
\text { Inhibited the negative effect of } \mathrm{Cu} \text { on plant membrane integrity }\end{array}$ & Benavides et al. [5] \\
\hline Vigna radiata $\mathrm{L}$. & $1.5 \mathrm{mM} \mathrm{CdCl}_{2}$ & $\begin{array}{l}\text { Increased Spd and } \\
\text { Spm content with } \\
\text { decrease the Put/PAs } \\
\text { ratio }\end{array}$ & Put, $0.2 \mathrm{mM}$ & $\begin{array}{ll} & \text { Increased Pro and NO content } \\
\text { - } & \text { Restored the growth inhibition under } \mathrm{Cd} \text { exposure } \\
\text { - } & \text { Increased the RWC, succulence and Chl content } \\
& \text { Decreased Cd accumulation in both roots and shoots }\end{array}$ & Nahar et al. [1] \\
\hline V. radiata & $\begin{array}{l}\mathrm{Zn}, 200 \mathrm{mg} \mathrm{kg}^{-1} \text { soil as } \\
\mathrm{ZnSO}_{4} \cdot 7 \mathrm{H}_{2} \mathrm{O}\end{array}$ & - & $1.0 \mathrm{mM} \mathrm{Spd}$, foliar application & $\begin{array}{l}\text { - Increased photosynthetic pigments, stomatal conductance, and } \\
\text { intercellular } \mathrm{CO}_{2} \text { concentration } \\
\text { - Increased plant growth, biomass, leaf area, and leaf water potential }\end{array}$ & Mir et al. [32] \\
\hline $\begin{array}{l}\text { Chlorella vulgaris } \\
\text { Beijerinck }\end{array}$ & $\begin{array}{l}100 \mu \mathrm{M} \text { of } \mathrm{Cu} \text { as } \\
\mathrm{Cu}\left(\mathrm{NO}_{3}\right)_{2} \cdot 3 \mathrm{H}_{2} \mathrm{O}\end{array}$ & - & $100 \mu \mathrm{M} \mathrm{Spd}$ & $\begin{array}{l}\text { - Increase cell number indicated growth stimulation } \\
\text { - Increased } \mathrm{Chl} a, \mathrm{Chl} b \text { and car content }\end{array}$ & Piotrowska-Niczyporuk et al. [33] \\
\hline C. vulgaris & $\begin{array}{l}100 \mu \mathrm{M} \mathrm{Cd} \text {, as } \\
\mathrm{Cd}\left(\mathrm{NO}_{3}\right)_{2} \cdot 4 \mathrm{H}_{2} \mathrm{O}\end{array}$ & - & $100 \mu \mathrm{M}$ Spd & $\begin{array}{ll}\text { - } & \text { Stimulated growth } \\
\text { - } & \text { Increased photosynthetic pigments (Chl } a, \mathrm{Chl} b \text { and car) }\end{array}$ & Piotrowska-Niczyporuk et al. [33] \\
\hline C. vulgaris & $100 \mu \mathrm{M}$ of $\mathrm{Pb} \mathrm{Pb}\left(\mathrm{NO}_{3}\right)_{2}$ & - & $100 \mu \mathrm{M}$ Spd & $\begin{array}{l}\text { - Stimulated growth } \\
\text { - } \quad \text { Increased photosynthetic pigments }\end{array}$ & Piotrowska-Niczyporuk et al. [33] \\
\hline Raphanus sativus L. & $1.2 \mathrm{mM} \mathrm{Cr}$ as $\left(\mathrm{K}_{2} \mathrm{CrO}_{4}\right)$ & $\begin{array}{l}\text { Increased Put and } \\
\text { Spd content }\end{array}$ & $1 \mathrm{mM} \mathrm{Spd}$ as cotreatment & $\begin{array}{l}\text { - Increased growth and biomass and total soluble sugar } \\
\text { - Increased photosynthetic pigments content and PSII quantum yield }\end{array}$ & Choudhary et al. [34] \\
\hline Poncirus trifoliata $\mathrm{L}$. & $\begin{array}{l}0,0.25,0.50,0.75,1.0,1.25 \\
\mathrm{mM} \mathrm{Cr} \text { as } \mathrm{K}_{2} \mathrm{Cr}_{2} \mathrm{O}_{7}\end{array}$ & $\begin{array}{l}\text { Increased PAs } \\
\text { content }\end{array}$ & - & $\begin{array}{ll} & \text { Enhanced PAs degradation enzymes (PAO and DAO) activities } \\
\text { - Increased PS conjugated PAs, and PIS-bound PAs improved growth } \\
\text { and development }\end{array}$ & Shahid et al. [27] \\
\hline Citrus reshni $\mathrm{L}$. & $\begin{array}{l}0,0.25,0.50,0.75,1.0,1.25 \\
\mathrm{mM} \mathrm{Cr} \text { as } \mathrm{K}_{2} \mathrm{Cr}_{2} \mathrm{O}_{7}\end{array}$ & $\begin{array}{l}\text { Increased PAs } \\
\text { content }\end{array}$ & - & $\begin{array}{l}\text { - Enhanced PAO and DAO activities } \\
\text { - Increased PS PAs and PIS PAs Improve growth and development }\end{array}$ & Shahid et al. [27] \\
\hline C. limonia Osbeck (CL) & $\begin{array}{l}0,0.25,0.50,0.75,1.0,1.25 \\
\mathrm{mM} \mathrm{Cr} \text { as } \mathrm{K}_{2} \mathrm{Cr}_{2} \mathrm{O}_{7}\end{array}$ & $\begin{array}{l}\text { Increased PAs } \\
\text { content }\end{array}$ & - & $\begin{array}{ll} & \text { Upregulated PAO and DAO enzyme activities } \\
\text { - } & \text { Increased PS PAs and PIS PAs Growth and development enhanced }\end{array}$ & Shahid et al. [27] \\
\hline Salix matsudana Koidz. & 0.05 and $0.10 \mathrm{mM} \mathrm{Cd}$ & $\begin{array}{l}\text { Increased } \\
\text { endogenous Spd } \\
\text { and Put contents }\end{array}$ & $\begin{array}{l}0.25 \mathrm{mM} \text { Spd as cotreatment for } 3 \\
\mathrm{~d}\end{array}$ & $\begin{array}{l}\text { - } \quad \text { Enhanced shoot and root growth } \\
\text { - Increased mineral contents i.e., } \mathrm{Cu}, \mathrm{Zn} \text {, and Fe } \\
\text { - } \quad \text { Increased BCF and TF of Cd in root and cutting } \\
\text { - } \quad \text { Increased BCF and TF in twig and leaf } \\
\end{array}$ & Tang et al. [35] \\
\hline Potamogeton crispus $\mathrm{L}$. & $30,50,70 \mu \mathrm{M} \mathrm{Cd}$ as $\mathrm{CdCl}_{2}$ & $\begin{array}{l}\text { Increased Put, PS } \\
\text { Put, and PIS Put } \\
\text { content }\end{array}$ & - & $\begin{array}{ll}\text { - } & \text { Membrane stabilization } \\
\text { Increased PAO and DAO activity }\end{array}$ & Yang et al. [36] \\
\hline
\end{tabular}


Kinnow mandarin (KM) grafted plants showed increased free, soluble-conjugated (PS conjugated PAs) and insoluble-bound PAs (PIS-bound PAs) content in leaves, when exposed to Cr-toxicity [27]. Therefore, increased PAs might be due to the stimulated activity of PAs anabolism enzymes (such as ADC, ODC, SAMDC, and SPDS) with lower activity of catabolic enzymes (polyamine oxidase: PAO and DAO) in plant leaves upon exposure to metal toxicity [27].

Howladar et al. [30] found an enhanced accumulation of endogenous Spd and Spm in Cd affected wheat, thus indicating a crucial plant-induced mechanism to avoid metal/metalloid(s) stress. Upon metal stress, the plant can regulate the accumulation and translocation with the increased endogenous PAs, where exogenous PAs stimulates this metal tolerance mechanism [1]. They studied the Cd-stressed mung bean response followed by PAs induced protection. Here, they used Put $(0.2 \mathrm{mM})$ against $1.5 \mathrm{mM} \mathrm{Cd}$ exposure. They found a lower biological accumulation coefficient (BAC) and translocation factor (TF), biological concentration factor (BCF), the value in mung bean after application of Put $(0.2 \mathrm{mM})$ in $1.5 \mathrm{mM} \mathrm{Cd}$-exposed seedlings, which resulted in lower Cd concentration in both root and shoot. Hence, they indicated the PA-induced lower metal/metalloid(s) accumulation as well as translocation from cell to cell. This inhibitory mechanism of PAs on metal/metalloid(s) uptake causes metal/metalloid(s) tolerance in plants. Not only this, but PAs also enhances the production and accumulation of phytochelatins (PC), which efficiently binds metal/metalloid(s) and this is considered as one of the most efficient metal/metalloid(s) detoxification strategy. Here, the presence of toxic metal/metalloid(s) induces the activity of PC synthesis by using the GSH as a substrate to form PCs, which bind metal ions and transport into the vacuole for safely carrying metal away from plant cells. According to research finding, PAs are able to increase GSH content and subsequently the PCs content under metal/metalloid(s) stress [1]. From a recent study of Howladar et al. [30], it is also clear that increased GSH content along with higher endogenous Spd and Spm in Si treated Cd stressed wheat plants provided tolerance against metal/metalloid(s) toxicity. Therefore, GSH itself involves metal/metalloid(s) chelation and detoxification [40]. Thus, maintaining higher GSH content is an essential mechanism for metal/metalloid(s) tolerance in plants. Many research findings confirmed about the PAs-induced elevated GSH content under metal/metalloid(s) stress as a tolerance mechanism $[1,11,30]$. Afterward, metal/metalloid(s) detoxification in plant showed improved plant growth osmotic status and Chl synthesis as signs of tolerance (Table 1). Nahar et al. [1] also found restoration of plant growth, relative water content (RWC), and Chl synthesis with higher Pro accumulation after Put treatment in Cd affected seedlings. They concluded that Put induced Pro accumulation at a higher amount might give the osmotic protection to plant. This greater Pro accumulation in the metal affected plant may be due to higher Pro synthesis for enhancing tolerance [41]. Other scientists have also reported about the PAs induced enhanced photosynthetic activity and functioning of photosynthetic apparatus under stress exposure although [42-44]. Exogenous use of PAs as seed treatment also induced better performance in T. aestivum regarding Cd stress [31]. Where, $0.25 \mathrm{mM} \mathrm{Spm}, 0.50 \mathrm{mM} \mathrm{Spd}$, and 1.0 mM Put was used to improve growth and yield under $2.0 \mathrm{mM}$ $\mathrm{Cd}$ exposure. They concluded that $1.0 \mathrm{mM}$ Put pretreatment was best regarding tolerance response compared to other PAs with greatest RWC, membrane stability, photosynthetic pigment synthesis, mineral nutrients content and osmoprotectant concentration [31]. Ghabriche et al. [45] explained that PAs (Put, Spd, and Spm) brought a reduction of Cd-induced damage in Inula crithmoides by stabilizing cellular structure through modulation of nutrition and ammonium/nitrate ratio.

\section{Polyamine-Induced Antioxidant Defense in Plants under Metal/Metalloid(S) Toxicity}

Like other abiotic stresses, metal/metalloid(s) also impose oxidative stress by generating excessive ROS (singlet oxygen: ${ }^{1} \mathrm{O}_{2}$; superoxide anion: $\mathrm{O}_{2}{ }^{\bullet}$; hydrogen peroxide: $\mathrm{H}_{2} \mathrm{O}_{2}$; and hydroxyl radical: $\mathrm{OH}^{\bullet}$ ), imbalance ROS homeostasis, and subsequent ROS-mediated damage of biomolecules such as protein, lipid, DNA, etc. [1]. Although plants are efficient with antioxidant defense, which fight back to scavenge ROS through both nonenzymatic and enzymatic antioxidants [1] (Figure 3), the efficiency of these processes may decrease gradually. At this point, PAs can actively participate in mitigating 
oxidative damage, through ROS scavenging $[46,47]$. Sometimes, $\mathrm{H}_{2} \mathrm{O}_{2}$ can be produced from the activities of DAO and PAO enzymes to degrade PAs, and thus causes stimulation of the antioxidative defense system. Moreover, PAs possess both anionic and cationic binding sites, which bestow radical scavenging and antioxidant properties, ultimately inhibit lipid peroxidation and oxidative reactions [48]. Polyamines contribute to binding the anions (phospholipid membranes and nucleic acids) in cells particularly prone to oxidations, whereas the cations efficiently prevent the generation of site-specific ROS, such as $\mathrm{OH}^{\bullet}$ and ${ }^{1} \mathrm{O}_{2}$ [49]. Polyamines also protect the membranes from oxidative attack by forming a complex with phospholipid and $\mathrm{Fe}^{2+}$ that can prevent the $\mathrm{Fe}^{2+}$ auto-oxidation [50]. $\mathrm{Yu}$ et al. [29] found that Put play a protective role in preventing Al-induced oxidative stress, where $\mathrm{H}_{2} \mathrm{O}_{2}$-generating both enzymes named CW-PAO (cell wall-PAO) and plasma membrane NADPH oxidase were inhibited. Moreover, Phenylpropanoid-PAs conjugates also react with reactive nitrogen species (RNS) and ROS and modulate the activities of enzymatic antioxidants (SOD; peroxidase: POD; and CAT), enhance ROS detoxification and subsequent inhibition of lipid peroxidation in metal-stressed seedlings [27] (Table 2).

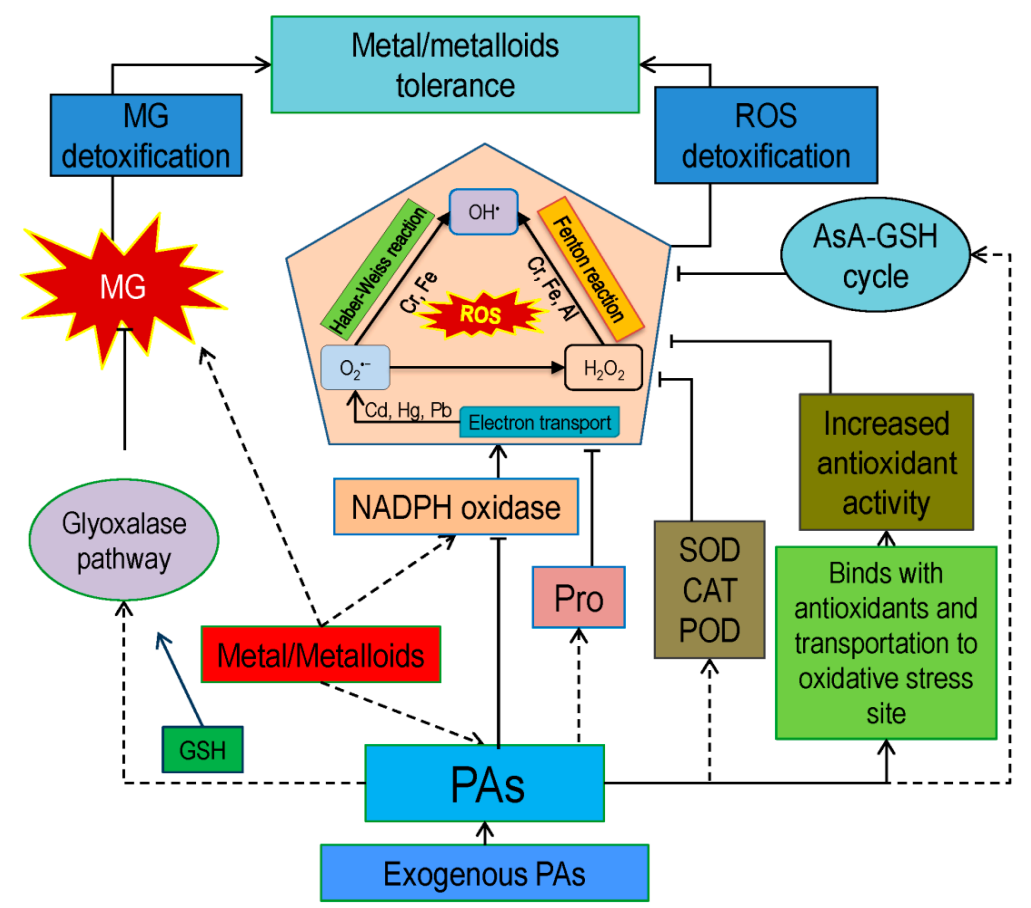

Figure 3. Polyamine-induced antioxidant defense and glyoxalase system under metal/ metalloid(s) stress. Dotted arrows represent stimulation/upregulation, solid arrows represent conversion/synthesis and " $\mathrm{T}$ " bar represent scavenging/detoxification.

Exogenous PAs stimulated the SOD, POD and CAT activities under stresses [1,47,51]. Thus, there is a positive correlation between PAs and antioxidants for ROS detoxification. Nahar et al. [1] showed the protective role of exogenous Put $(0.2 \mathrm{mM})$ under $\mathrm{Cd}(1.5 \mathrm{mM})$ toxicity in Mung bean. Their research group found that the application of Put positively modulated endogenous PAs (Put, Spd, Spm) accumulation and this free PAs contributed to the reduction of oxidative damage through enhancing the antioxidant defense system. They also found, both enzymatic (SOD, CAT, APX, DHAR, GR, GST, and GPX) and nonenzymatic (AsA and GSH) antioxidants become up stimulated. Consequently, excessively produced ROS dismutated to nontoxic compound and plant got relief from oxidative stress by showing lower ROS generation compared to stressed plants. Together with this, they also found that PAs detoxified the toxic methylglyoxal (MG, another vital cytotoxic compound, which also causes oxidative stress) by enhancing the glyoxalase system through the upregulation of both glyoxalase I (Gly I) and glyoxalase II (Gly II) enzymes. Thus, PAs, including Put, relieve oxidative stress directly and indirectly. 
Table 2. Polyamine mediated antioxidant defense in different plant species under metal/metalloid stresses.

\begin{tabular}{|c|c|c|c|c|c|}
\hline Crop Species & Metal Exposure & $\begin{array}{c}\text { Changes in } \\
\text { Endogenous PAs Level }\end{array}$ & Exogenous PAs Applications & Antioxidant Defense System & References \\
\hline Triticum aestivum $\mathrm{L}$. & $\begin{array}{l}2 \mathrm{mMCd} \text { as } \mathrm{CdCl}_{2} \text { and } 2 \\
\mathrm{mM} \text { as } \mathrm{PbCl}_{2} \text { for } 45 \mathrm{~d}\end{array}$ & - & $\begin{array}{l}0.25 \mathrm{mM} \text { Spm, } 0.50 \mathrm{mM} \text { Spd, and } \\
1 \mathrm{mM} \text { Put as seed priming or as a } \\
\text { foliar spray at } 20,40 \text {, and } 60 \mathrm{DAS}\end{array}$ & $\begin{array}{l}\text { Enhanced the activity of SOD, CAT, POD, and GR } \\
\text { - Improved ascorbic acid oxidase (AAO), and polyphenol oxidase } \\
\text { (PPO) activities }\end{array}$ & Taie et al. [12] \\
\hline T. aestivum & $2 \mathrm{mM}$ as $\mathrm{PbCl}_{2}$ for $45 \mathrm{~d}$ & - & $\begin{array}{l}0.25 \mathrm{mM} \text { Spm, } 0.50 \mathrm{mM} \text { Spd, and } \\
1 \mathrm{mM} \text { Put as seed priming or as a } \\
\text { foliar spray at } 20,40 \text { and } 60 \text { DAS }\end{array}$ & $\begin{array}{l}\text { Enhanced the activity of SOD, CAT, POD, GR } \\
\text { - Improved ascorbic acid oxidase (AAO), and polyphenol oxidase } \\
\text { (PPO) activities }\end{array}$ & Taie et al. [12] \\
\hline T. aestivum & $2 \mathrm{mMCdCl}_{2}$ for $58 \mathrm{~d}$ & - & $\begin{array}{l}0.25 \mathrm{mM} \text { Spm, } 0.50 \mathrm{mM} \mathrm{Spd}, \\
1.0 \mathrm{mM} \text { Put as seed priming and } \\
\text { later foliar spraying }\end{array}$ & $\begin{array}{l}\text { - Increased POD and CAT activity } \\
\text { - Decreased SOD activity }\end{array}$ & Rady et al. [28] \\
\hline T. aestivum & $30 \mu \mathrm{M} \mathrm{AlCl}{ }_{3}$ & Increased Spd & Put, $2 \mathrm{mM}$ as cotreatment & $\begin{array}{l}\text { - Inhibited plasma membrane NADPH oxidase and CW-PAO activity } \\
\text { in Al-stressed wheat and thus reduced } \mathrm{H}_{2} \mathrm{O}_{2} \text { accumulation } \\
\text { - Decreased SOD, CAT, POD, APX, GR, GST activities } \\
\text { - } \quad \text { Decreased LOX activity and Thiobarbituric acid (TBARS) content }\end{array}$ & Yu et al. [29] \\
\hline T. aestivum & $2 \mathrm{mMCd}$ & $\begin{array}{l}\text { Increased endogenous } \\
\text { Spm and Spd upon Cd } \\
\text { exposure }\end{array}$ & - & - Increased AsA, GSH content with higher SOD, CAT, POD activity & Howladar et al. [30] \\
\hline T. aestivum & $1 \mathrm{mMCd}$ as $\mathrm{CdCl}_{2}$ & $\begin{array}{l}\text { Increased PAs content } \\
\text { by pretreated seedlings } \\
\text { under stress affection }\end{array}$ & $\begin{array}{l}2 \mathrm{mM} \mathrm{Spd} \mathrm{or} 2 \mathrm{mM} \text { Spm as a seed } \\
\text { treatment for } 6 \mathrm{~h}\end{array}$ & $\begin{array}{ll}\text { - } & \text { Increased AsA and GSH content } \\
\text { - } & \text { Enhanced SOD and CAT activity } \\
\text { - } & \text { Decreased POX and APX activity } \\
\text { Lowered } \mathrm{H}_{2} \mathrm{O}_{2} \text { and MDA generation }\end{array}$ & Rady and Hemida [11] \\
\hline T. aestivum & $0.5 \mathrm{mM} \mathrm{Cd}$ as $\mathrm{CdCl}_{2}$ & $\begin{array}{l}\text { Increased PAs content } \\
\text { such as Put, Spd, and } \\
\text { Spm }\end{array}$ & 0.5 and $1.0 \mathrm{mM} \mathrm{Spm}$ & $\begin{array}{l}\text { - } \quad \text { Decreased ADC and ODC with lowered DAO activities } \\
\text { - } \quad \text { Increased SOD, GPX, with increased of GR } \\
\text { - Increased GSH content under } \mathrm{Cd} \text { stressed the plant } \\
\text { treated plant }\end{array}$ & Groppa et al. [37] \\
\hline T. aestivum & $0.5 \mathrm{mM} \mathrm{Cu}$ as $\mathrm{CuCl}_{2}$ & - & 0.5 and $1.0 \mathrm{mM} \mathrm{Spm}$ & $\begin{array}{l}\text { - } \quad \text { Decreased ADC and ODC with lowered DAO activities } \\
\text { - } \quad \text { Increased SOD, GPX, with increased of GR } \\
\text { - Increased GSH content under } \mathrm{Cd} \text { stressed the plant } \\
\text { treated plant }\end{array}$ & Groppa et al. [37] \\
\hline Oryza sativa $\mathrm{L}$. & $5 \mathrm{mMCdCl}_{2}$ & - & $\begin{array}{l}5 \mathrm{mM} \text { Put, } 5 \mathrm{mM} \mathrm{Spd} \text {, and } 5 \mathrm{mM} \\
\text { Spm }\end{array}$ & $\begin{array}{ll}\text { - } & \text { Increased protein content under } \mathrm{Cd} \text { exposure } \\
\text { - } & \text { Increased } \mathrm{AsA} \text { and } \mathrm{GSH} \text { content at } \mathrm{Cd} \text { stressed rice } \\
\text { - } & \text { Decreased } \mathrm{SOD}, \mathrm{CAT}, \mathrm{APX}, \mathrm{GR} \text { and POX activity } \\
& \text { Reduced } \mathrm{H}_{2} \mathrm{O}_{2} \text { and } \mathrm{MDA} \text { content significantly } \\
\end{array}$ & Hsu and Kao [38] \\
\hline Vigna radiata & $1.5 \mathrm{mMCdCl}_{2}$ & $\begin{array}{l}\text { Increased Spd and Spd } \\
\text { content with decrease } \\
\text { the Put/PAs ratio }\end{array}$ & $\begin{array}{l}\text { Put, } 0.2 \mathrm{mM} \text {, as pretreatment for } \\
24 \mathrm{~h}\end{array}$ & $\begin{array}{l}\text { - } \quad \text { Boosted up AsA and GSH content, while DHA content was decreased } \\
\text { - Increases AsA/DHA ratio and decreased GSH/GSSG ratio } \\
\text { - } \quad \text { Decreased SOD, CAT, APX, MDHAR, DHAR and GST activities } \\
\text { and lipoxygenase (LOX) action with lower malondialdehyde (MDA) } \\
\text { - Improved the glyoxalase system by increasing Gly II activity with } \\
\text { lowered MG content }\end{array}$ & Nahar et al. [1] \\
\hline
\end{tabular}


Table 2. Cont

\begin{tabular}{|c|c|c|c|c|c|}
\hline Crop Species & Metal Exposure & $\begin{array}{c}\text { Changes in } \\
\text { Endogenous PAs Level }\end{array}$ & Exogenous PAs Applications & Antioxidant Defense System & References \\
\hline V. radiata & $\begin{array}{l}200 \mathrm{mg} \mathrm{kg}^{-1} \text { soil as } \\
\mathrm{ZnSO}_{4} \cdot 7 \mathrm{H}_{2} \mathrm{O}\end{array}$ & - & $1.0 \mathrm{mM}$ Spd, foliar application & - Increased SOD, CAT and POX activity & Mir et al. [32] \\
\hline $\begin{array}{l}\text { Chlorella vulgaris } \\
\text { Beijerinck }\end{array}$ & $\begin{array}{l}100 \mu \mathrm{M} \text { of } \mathrm{Cd} \text { as } \\
\mathrm{Cd}\left(\mathrm{NO}_{3}\right)_{2} \cdot 4 \mathrm{H}_{2} \mathrm{O}\end{array}$ & - & $100 \mu \mathrm{M}$ Spd & $\begin{array}{ll}\text { - } & \text { Increased AsA and GSH accumulation } \\
\text { - } & \text { Increased } \mathrm{SOD}, \mathrm{CAT} \text {, and APX activity } \\
\end{array}$ & Piotrowska-Niczyporuk et al. [33] \\
\hline C. vulgaris & $100 \mu \mathrm{M} \mathrm{Pb}$ as, $\mathrm{Pb}\left(\mathrm{NO}_{3}\right)_{2}$ & - & $100 \mu \mathrm{M}$ Spd & $\begin{array}{ll} & \text { Increased AsA and GSH accumulation } \\
\text { - } & \text { Increased } \mathrm{SOD}, \mathrm{CAT} \text {, and APX activity } \\
\text { - } & \text { Decreased } \mathrm{H}_{2} \mathrm{O}_{2} \text { and MDA generation }\end{array}$ & Piotrowska-Niczyporuk et al. [33] \\
\hline C. vulgaris & $\begin{array}{l}100 \mu \mathrm{M} \mathrm{Cu} \text { as } \\
\mathrm{Cu}\left(\mathrm{NO}_{3}\right)_{2} \cdot 3 \mathrm{H}_{2} \mathrm{O}\end{array}$ & - & $100 \mu \mathrm{M} \mathrm{Spd}$ & $\begin{array}{ll}\text { - } & \text { Increased AsA and GSH accumulation } \\
\text { - } & \text { Increased } \mathrm{SOD}, \mathrm{CAT} \text {, and APX activity } \\
\end{array}$ & Piotrowska-Niczyporuk et al. [33] \\
\hline Raphanus sativus & $1.2 \mathrm{mM} \mathrm{Cr}$ as $\left(\mathrm{K}_{2} \mathrm{CrO}_{4}\right)$ & $\begin{array}{l}\text { Increased Put and Spd } \\
\text { content }\end{array}$ & $1 \mathrm{mM} \mathrm{Spd}$ as cotreatment & $\begin{array}{ll}\text { - Increased GSH, AsA, contents } \\
\text { - } & \text { Enhanced accumulation of osmolyte (Pro, GB, and Phenol) } \\
& \text { Increased } \mathrm{SOD} \text {, and GR activity where decrease Cat and POD } \\
\text { - } & \text { Lowitiered in } \mathrm{Cr} \text {-stressed plants } \\
\text { - } & \text { Decreased } \mathrm{MDA} \text { and } \mathrm{H}_{2} \mathrm{O}_{2} \text { production } \\
\end{array}$ & Choudhary et al. [34] \\
\hline Salix matsudana Koidz. & 0.05 and $0.10 \mathrm{mM} \mathrm{Cd}$ & $\begin{array}{l}\text { Increased endogenous } \\
\text { Spd and Put contents }\end{array}$ & $\begin{array}{l}0.25 \mathrm{mM} \text { Spd as cotreatment for } \\
3 \mathrm{~d}\end{array}$ & $\begin{array}{ll} & \text { Upregulated SOD, CAT, GR GPX, and APX activities } \\
\text { - } & \text { Enhanced AsA and GSH contents } \\
\text { - Increased endogenous NO content } & \text { Decreased } \mathrm{MDA}, \mathrm{O}_{2}{ }^{-}, \text {, and } \mathrm{H}_{2} \mathrm{O}_{2} \text { production } \\
\end{array}$ & Tang et al. [35] \\
\hline Helianthus annuиs & $0.5 \mathrm{mM} \mathrm{Cd}$ as $\mathrm{CdCl}_{2}$ & $\begin{array}{l}\text { Increased endogenous } \\
\text { Put and Spd levels }\end{array}$ & $1.0 \mathrm{mM}$ Spd and Spm & $\begin{array}{l}\text { - Increased APX and GR activity under Cd stress while reducing the } \\
\text { SOD activity } \\
\text { Enhanced the SOD and GR activity with lower APX activity under } \\
\text { Cu stressed plant }\end{array}$ & Groppa et al. [39] \\
\hline H. anпuиs & $0.5 \mathrm{mM} \mathrm{Cu}$ as $\mathrm{CuCl}_{2}$ & $\begin{array}{l}\text { Increased endogenous } \\
\text { Put and Spd levels }\end{array}$ & $1.0 \mathrm{mM}$ Spd and Spm & $\begin{array}{l}\text { - Increased APX and GR activity under Cd stress while reducing the } \\
\text { SOD activity } \\
\text { - Enhanced the SOD and GR activity with lower APX activity under } \\
\text { Cu stressed plant }\end{array}$ & Groppa et al. [39] \\
\hline
\end{tabular}


Polyamines like Spd increase plant tolerance to metal toxicity by enhancing AsA and GSH pool and subsequently balancing redox homeostasis. For example, Spd protects $R$. sativus from negative impacts of Cr [34]. Yang et al. [36] demonstrated the PAs involvement in Cd affected Potamogeton crispus plant. They found that upon $\mathrm{Cd}$ exposure endogenous free PAs content increased along with PIs bond Put content. Afterward, AsA and GSH contents were also increased, which further contributed to ROS detoxification. Therefore, in light of the above discussion, it is clear that PAs modulate the antioxidant defense system under metal/metalloid(s) toxicity for inhibiting ROS induced oxidative damages.

\section{Polyamine-Induced Metal/Metalloid(s) Chelation and Phytoremediation in Plants}

Under metal/metalloid(s) stress the common defense mechanisms evolved by plants are exclusion, complexation, compartmentalization, and metal-binding protein synthesis and ion chelation [52-54]. Among them, the most important mechanism is chelation, which maintains the free metal ion concentration in the cytoplasm via detoxification. Chelation can be accomplished by thiol compounds that contain $\gamma$-Glu-Cys-Gly, phytochelatins (PCs), metallothioneins (MTs), and sulfhydryl/thiol groups (tripeptide glutathione, and GSH)) and also non-thiol compounds, for example, organic acids and amino acids [53,55] (Figure 4). Amino acids and their derivatives play a vital role in chelation of different metal/metalloid(s) and tolerance in plants. However, efficient mechanisms for chelation by amino acids are not so conclusive [40]. Amino acid derivatives, PAs are recommended as one of the vital metal/metalloid(s) chelators. For example, after application of PAs in European pear (transgenic line) the chelation of metals $(\mathrm{Zn}, \mathrm{Cd}$, and $\mathrm{Pb}$ ) increased, thus enhanced metal tolerance [56].

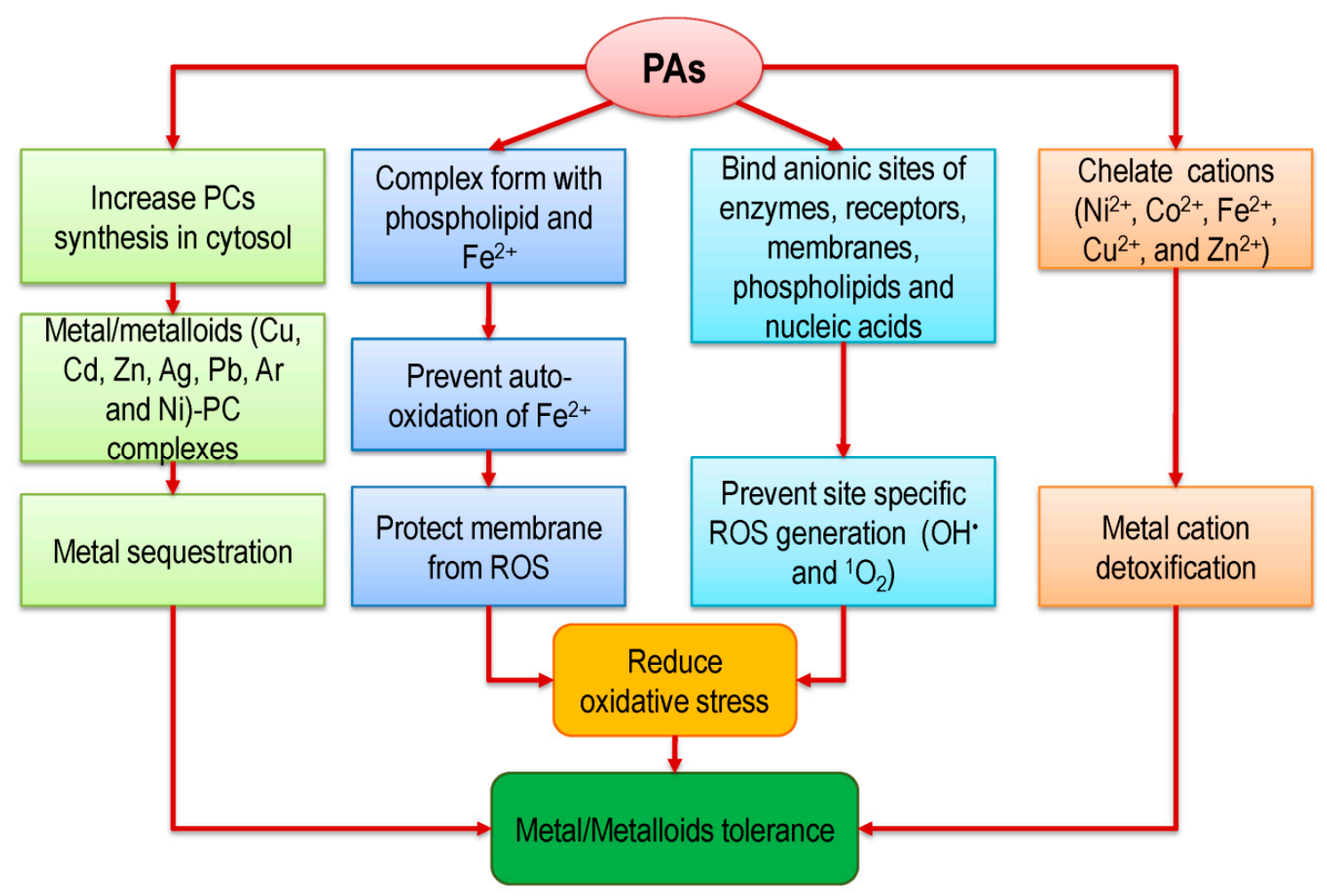

Figure 4. Proposed mechanisms of PA-induced metal chelation in plants.

Polyamines are cationic $\left(\mathrm{Put}^{2+}, \mathrm{Spd}^{3+}\right.$, and $\left.\mathrm{Spm}^{4+}\right)$, and hence have the ability to bind nucleic acids [25,57]. As cations, PAs interact with anions, and they can imitate and compete for the same binding sites with $\mathrm{Mg}^{2+}$ and $\mathrm{Ca}^{2+}$ on enzymes, receptors, and membranes. For cellular protection, PAs also bind some cations including $\mathrm{Cu}^{2+}$ and $\mathrm{Fe}^{3+}$ [49]. However, the presence of several complex-forming groups in the same molecule regulates and promotes chelation effects. Therefore, PAs with a high number of $\mathrm{N}$-groups act as a stronger chelator or enhance chelation mechanism [1,49]. The synthesis 
of PCs under metal stress is another vital strategy of plants to tolerate metal/metalloid(s) toxicity at different developmental stages, which is influenced by PAs [58]. Several researchers found that exogenous PAs application increased the cellular PCs content [1,34]. While Groppa et al. [39] found that there are no effects of PAs on PCs biosynthesis, Nahar et al. [1] found that, Put application increased the content of PCs in the Cd-affected mung bean seedlings, which indicate the interaction of PAs for Cd chelation. Similarly, Spd application in Raphanus sativus L. plant under Cr-stress increased PCs content [34]. Contrary, Pál et al. [58] found that pre-treatment of Put prevented the synthesis of PCs in rice at the molecular and gene expression levels.

If we think from an economic point of view, phytoremediation can be useful for reducing risk of metal/metalloid(s), gradually improves soil quality, phytoextraction of high market value metals [59]. Moreover, using fast-growing timber trees, the toxic metal/metalloid(s) could be trapped in the wood [60]. Thus, the success of phytoremediation mainly depends on shoot metal concentration. As previously described, PAs with a high number of N-groups act as a stronger chelator or enhance chelation mechanism. Polyamines are already used as an adsorbent to purify water. Keymirov [61] reported that natural montmorillonite modified by PAs can remove metal/metalloid(s) ions from water in the series $\mathrm{Cu}(\mathrm{II})>\mathrm{Ni}(\mathrm{II})>\mathrm{Zn}(\mathrm{II})>\mathrm{Cd}(\mathrm{II})$. However, in plants, a variety of molecules control and regulate the journey of metal/metalloid(s) ions from the soil solution to the vacuoles, where some perform cross-membrane transport when others functions in their complexation and subsequent sequestration. There are contradictory reports showing the PAs induced phytoremediation regarding the metal/metalloid(s) uptake and translocation but most of the researchers' affirmed that the PAs increase formation of PCs and sequestering metal/metalloid(s) in vacuoles. Previous reports suggested that in $\mathrm{Cd}$-stressed mung bean seedlings, the root $\mathrm{Cd}$ content was much higher than the shoot $\mathrm{Cd}$ content, while BCF, TF, and BAC also increased [62]. On the other hand, Shevyakova et al. [63] reported that PAs treatment increased the capability of $\mathrm{Ni}$ accumulation by $2-3$ times and reduced Ni toxicity by chelation. Again Pál et al. [58] reported that PAs application increased shoot Cd content by 5 -fold mainly through chelation. Polyamines also induce the formation of PCs [58,62], which further accelerate the phytoremediation process. Therefore, in light of the previous discussion, it can be portrayed that PAs induced direct metal/metalloid(s) chelation or indirect chelation through GSH dependent PCs are the main valuables for the PAs modulated phytoremediation process. Thus, nevertheless PAs reduce metal/metalloid(s) translocation, yet they can be a potential candidate enhancing the phytoremediation process.

Besides, PAs induced metal/metalloid(s) chelation opens a new portal to enrich our foods with various micronutrients. Soudek et al. [64] reported that vegetables grown on micronutrients (Fe or $\mathrm{Zn}$ ) enriched medium might exceed their uptake and cause adverse health effects for consumers. Here, PAs like Put is able to increase or decrease metal/metalloid(s) micronutrient uptake depending on the plant species. On the other hand, their findings also suggested that the consumption of these enriched vegetables could be a solution for nutrient deficiency in our diet. Although these studies are still in preliminary stages, it is expected that more interesting result will come in the future. Therefore, further research should be highlighted on the PAs induced metal/metalloid(s) transportation from root to shoot, PAs induced GSH content upregulation and PCs synthesis to upscaled the phytoremediation process in plants. Moreover, PAs induced metal/metalloid(s) chelation based food fortification might be a new focused area in the future.

\section{Interaction of Polyamines with other Molecules in Conferring Metal/Metalloids Tolerance in Plants}

In the previous sections, we discussed the metabolism of PAs in the plant. We also highlighted PAs-assisted metal/metalloid(s) tolerance and the antioxidant defense under metal/metalloid(s) toxicity along with metal/metalloid(s) chelation and sequestration in plants. Besides, these PAs play interacting role with other biomolecules to retrieve of metal/metalloid(s) stress, including interaction with osmolyte (proline: Pro; glycine betaine: GB), compatible solute (GABA), macromolecules (DNA and RNA) which 
contribute in reducing ROS generation, scavenging and signaling, enhancing antioxidant metabolisms, signaling role with other signaling molecules and regulating ion channels ([24,65]; Figure 5). Moreover, it was reported that increased PAs contents regulate the gene expression of various plant secondary metabolites and signaling molecules. Hence, in this section, we will summarize the cross-talk and interaction of PAs with biomolecules for metal/metalloid(s) tolerance.

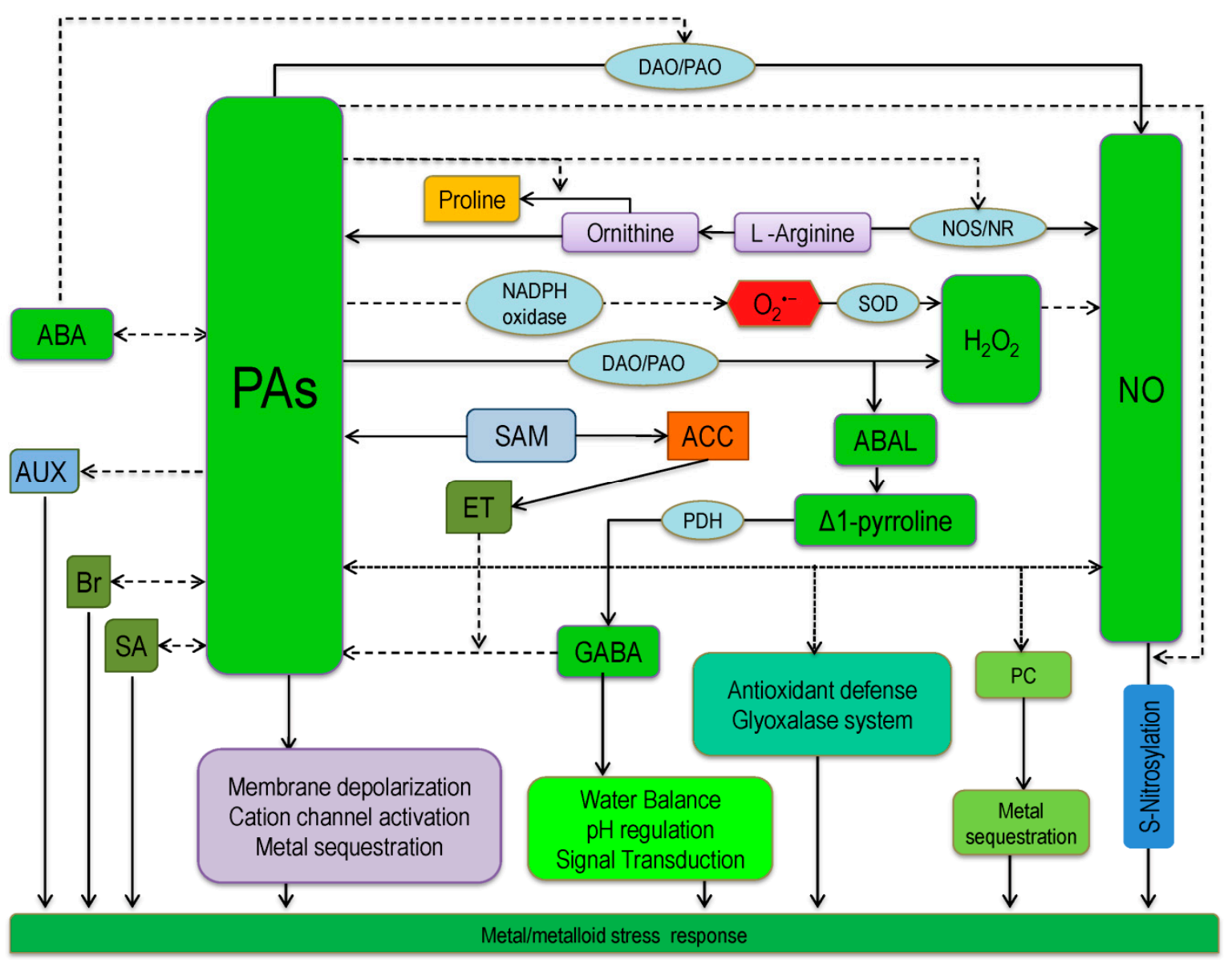

Figure 5. Interaction of polyamines with other molecules conferring metal/metalloid stress in plants. Dotted arrows represent stimulation/upregulation and solid arrows represent conversion/synthesis.

\subsection{Nitric Oxide and Polyamines Cross-talk and the Reversal of Metal Phytotoxicity}

Being gaseous with diffusible nature, NO regulates various physiological and developmental processes as an intra- and intercellular messenger along with activation of plant stress responses. Alike NO, PAs also play diverse roles in regulating many physiological processes, including organogenesis, embryogenesis, flower and fruit development, and senescence mechanism [25]. Therefore, there might be a link between NO and PAs metabolism, which is partially reported previously. In the biosynthetic pathway, PAs and NO both share Arg as a common precursor [66], hence PAs are supposed to modulate the Arg-linked NO synthase (NOS) and nitrate reductase (NR) pathways [67]. Rapid NO accumulation without a lag phase was reported in Arabidopsis after Spd and Spm treatments, whereas Put had little or no effect [68]. Opposite to this finding, PA-induced NO production was observed in Arabidopsis NR impaired double mutant nia1nia2, showing NR is not the only contributor to NO production. Yet, experimental evidence on PA-induced NO biosynthesis proposed new insights that the PAs can be directly converted to NO with the activity of PAO and DAO [15]. Therefore, NO attributes to many functions on PA-mediated metal stress responses. In addition, $\mathrm{NO}$ and PAs have some common roles under stress conditions, and hence they linked each other, conferring the metal/metalloid(s) stress [1]. Some researchers hypothesized that NO directly or 
indirectly seal the slits of PAs induced physiological effects to mitigate metal/metalloid(s) stress [1,69]. Exogenously applied Put and/or SNP (NO donor) increased endogenous PAs (Put, Spd, and Spm) and NO content; where MG detoxification was observed by the improved glyoxalase system along with better physiology and growth [1]. They also found higher PC contents in Cd-affected seedlings, which suggested the role of both PAs and NO in upregulating the PC biosynthesis along with Cd sequestration. In this study combined application of PAs and NO showed better effects, which showed the possible cross-talk between $\mathrm{NO}$ and PAs to confer Cd-tolerance.

\subsection{Reactive Oxygen Species and Polyamines Interaction and the Reversal of Metal Phytotoxicity}

Another vital double-edged aspect is that PAs can be sources for ROS production as well as efficient ROS scavengers, and also play a role in balancing redox homeostasis in plant tissue [70]. During PAs catabolism two PAs catabolizing enzymes, PAO and DAO modulate the endogenous PAs levels, where, $\mathrm{H}_{2} \mathrm{O}_{2}$ is liberated in the apoplast and peroxisomes [71]. However, as a signal transduction molecule $\mathrm{H}_{2} \mathrm{O}_{2}$ is able to modulate various physiological and biochemical processes, including influencing ion channels for stomatal regulation, activating the stress response via the MAPK cascade, etc. [72] while activating the antioxidative system under metal/metalloid stress conditions [29]. Hence, PAs, especially Spm enhance the activity of NADPH-oxidase and produce $\mathrm{O}_{2}{ }^{\bullet-}$. Further, $\mathrm{O}_{2}{ }^{\bullet-}$ turns into $\mathrm{H}_{2} \mathrm{O}_{2}$ by the spontaneous involvement of SOD. The ratio of $\mathrm{O}_{2}{ }^{\bullet-}$ and $\mathrm{H}_{2} \mathrm{O}_{2}$ is a vital signal to the transcription process [73], hence can mediate PAs induced plant adaptation to metal/metalloid(s) stress $[29,74]$.

\subsection{Interaction of Polyamines with GABA and Pro Conferring Metal/Metalloid(s) Stress}

The role of GABA is well established as a neurotransmitter in animal cells. In plants, increases in GABA level are suggested to contribute to stress protection through the regulation of cellular $\mathrm{pH}$, acting as osmoregulator or as signaling molecules. In the PAs metabolic pathway 4-aminobutanal (ABAL), $\mathrm{H}_{2} \mathrm{O}_{2}$, and $\mathrm{NH}_{3}$ are produced as a byproduct with the activity of PAO and DAO [75]. Produced ABAL is then instinctively converted to form $\Delta^{1}$-pyrroline, which further converted into GABA by pyrroline dehydrogenase (PDH). Hence, enhanced PAs metabolism may lead to increased GABA accumulation, as well as stress tolerance [76]. On the other hand, GABA accumulation has been suggested to reduce the oxidative damage caused by ROS, leading to improved tolerance to oxidative stresses [77]. These observations suggest the intrinsic relationship between PAs and GABA during abiotic stress. The exogenous GABA application also influences PAs metabolism, and hence confers stress tolerance. Increased metal chelation and activation of antioxidant defense and glyoxalase systems to alleviate the oxidative damage from ROS and MG by exogenous GABA application has been reported in Cr-exposed Brassica seedlings [78], and both $\mathrm{Al}$ and acidity stressed barley seedlings [79]. Moreover, GABA activates multiple mechanisms involved in signaling cascades, regulation of protein degradation, hormone biosynthesis, ROS metabolism and PAs metabolism in response to stress. Shi et al. [80] reported that exogenous GABA influences the gene expression of genes involved in PAs biosynthesis in response to abiotic stress. Furthermore, GABA reduced the DAO gene expression as well as DAO activity and alleviated PAs metabolism, especially reduced Put catabolism to GABA [81,82]. These findings speculated the role of GABA as an alternative modulator of tolerance by regulation of PAs metabolism in plants and suggested that under stress situation, GABA increases PAs levels by suppressing its formation. However, although several reports under abiotic stress discussed the interacting role of PAs and GABA, still there is a shortage of literature evaluating the cross-talk between PAs and GABA for conferring abiotic stress tolerance especially metal/metalloid(s) stress. Therefore, the roles for GABA under metal/metalloid(s) stress need to be defined, especially the PAs and GABA regulatory mechanisms. Further studies are also needed by combining genomic and metabolomic approaches to clarify the interconnection between GABA and PAs, together with their secondary metabolites in conferring metal/metalloid(s) stress tolerance in plants. 
The cross-talk between PAs and Pro in regulating stress tolerance has also been widely described. Proline, alanine (Ala), glutamine (Glu), and GABA are all GABA shunt-related metabolites that accumulate in response to ROS production in plants [83,84]. The exogenous application of PAs induced stress tolerance and Pro accumulation in mung bean exposed to $\mathrm{Cd}$ and $\mathrm{Al}$ toxicity $[1,62,85]$. Cvikrová et al. [86] analyzed P5CSF129A transgenic tobacco, which accumulated higher Pro, Put and Spd levels, showing dehydration tolerance and recovery capacity than wild type. Therefore, new studies combining genomic and metabolomic approaches are needed to clarify, how PAs increases Pro metabolism, and whether other metabolites interconnected, regulating osmolyte synthesis for conferring stress tolerance under metal/metalloid(s) toxicity.

\subsection{Interaction of Plant Hormones and Other Hormone-Like Protective Molecules with Polyamines}

Although the PAs and phytohormones (auxins: AUX; cytokinins: CK; gibberellins: GA; abscisic acid: ABA; brassinosteroids: Br; ET; jasmonic acids: JA; salicylic acid: SA) are interrelated, and their activity and interactions are not yet elucidated fully. Agami [87] found the contribution of indole acetic acid (IAA) in Spd induced Cu-stress tolerance in T. aestivum. Previously we discussed the interacting role of PAs with NO. Here, it is worthy of mentioning that NO take part as an intermediate signaling molecule in AUX, CK, ABA, and ET signaling. Transgenic plants overexpressing ADC2 showed the lower content of GA1, GA4, and GA9, and reduced the AtGA20ox1, AtGA3ox1 and AtGA3ox3 transcripts expressions [15], suggesting that Put accumulation inhibits GA synthesis. Similarly, the mutant SAMDC4 exhibited hyposensitivity to exogenous AUX and hypersensitivity to CK treatments. These findings suggested that PAs increases AUX sensitivity, and reduce CK biosynthesis or signaling [88].

There are controversies between the interaction of PAs and ET, whether the relationship is antagonistic or synergistic. Yin et al. [89] reported that synergistic interactions were exhibited between PAs and ET, where they found decreased 1-aminocyclopropane-1-carboxylic-acid (ACC) levels with the increase of PAs concentration, hence, the leaf senescence slowed down. Some researchers termed the relationship as antagonistic as ET enhance senescence while PAs inhibit [90]. Yin et al. [89] observed ACS activity is inhibited by Put, which lowered ET production and eventually alleviated Al-induced root inhibition. Hence, two pathways were not strictly antagonistic. Yet again, NO can also modulate ET biosynthesis and its signaling [91]. Through $S$-nitrosylation, NO can change the activity of methionine adenosyltransferase (MAT), and hence causes a reduced formation SAM, which is obvious for ACC generation and ET production [92,93]. Under metal/metalloid(s) toxicity, especially during $\mathrm{Cd}$-exposure, $\mathrm{Cd}$ modulated the genes encoding the proteins; those are involved in ET and PAs metabolism, as well as NO generation, Mitogen-activated protein kinases (MAPKs) cascades and regulate other gene expressions in G. max seedlings, including ACS, SAMDC, MAPK, and MAPKK2, and DOF1, MYBZ2, and bZIP62 transcription factors in Cd tolerance [94].

As ABA is very much linked to dehydration-induced by metal/metalloid(s) stress [1], hence, ABA modulated PAs metabolism during the transcriptional stage, and regulate the expression of PAs biosynthesis pathway genes $A D C 2$, SPDS1, and SPMS [13]. On the other hand increase in ABA synthesis via Put accumulation; found to be upregulated in $A D C$ overexpressing transgenic plants $[95,96]$. On the other hand, suppression of $A D C$ gene (both $a d c 1$ and $a d c 2$ ) resulted in the down-regulation of NCED3 expression and hence reduced ABA-regulating genes expression. However, exogenous Put supplementation resulted in better tolerance to these plants under chilling stress [97].

Besides the regulatory role of $\mathrm{Br}$ as phytohormones in plant growth and physiological processes, it also confers abiotic stress tolerance singly or in keeping relations with ABA, AUX, CK, ET, JA, SA, and GA. A relationship between $\mathrm{Br}$ and PAs is recommended by the fact that epibrassinolide (EBL) treatment influences the level of PAs, and can alleviate $\mathrm{Cu}^{2+}$ stress [98]. Exogenous application of both EBL and Spd as cotreatment was more effective than their sole treatments to confer Cr tolerance in R. sativus [34]. On the other hand, $\mathrm{Zn}$ toxicity was fully conquered by the combined application of EBL and Spd [32]. Then, Mir et al. [32] recommended EBL and Spd as potential growth enhancers that 
promote biochemical parameters along with plant growth under Zn stress. Salicylic acid is regarded as a signal molecule to modulate defense mechanisms in plants from long before. Yet, the parallel alterations in SA and PAs contents of metal/metalloid(s) stressed affected plants have only been found in very few studies. However, some recent reports suggested that SA treatment influences PAs metabolism [99], but the exact cross-talk mechanisms under metal/metalloid(s) stress conditions are still elusive.

\subsection{Polyamine Interacts with Ion Channels Modulate Metal/Metalloid(S) Stress Tolerance}

Under metal/metalloid stress, the potential targets of ROS are the ion channels. Both $\mathrm{H}_{2} \mathrm{O}_{2}$ and $\mathrm{OH}^{\bullet}$ modulate a number of ion channels, includes $\mathrm{Ca}^{+}$influx and $\mathrm{K}^{+}$efflux channels $[100,101]$. Moreover, PAs-induced NO generation influenced by $\mathrm{K}^{+}$channel inhibition, stimulating $\mathrm{H}^{+}$-ATPase as well as PAs-activated $\mathrm{Ca}^{2+}$ efflux [101]. In addition, PAs actively regulate ion channel activity by membrane depolarization [71]; while PAs are also capable of blocking vacuolar cation channels $\left(\mathrm{Spm}^{4+}>\mathrm{Spd}^{3+}>\mathrm{Put}^{2+}\right)$. Thus, assist in vacuolar metal sequestration during stress [101].

Like metal/metalloid stress most of the abiotic stress responses share a variety of common elements, which are potential points of cross-talk. It is evident that PAs are the switching hub and interconnected at various levels. Among the biological signal transduction molecules $\mathrm{H}_{2} \mathrm{O}_{2}$ and $\mathrm{NO}$ are the main possible links between PAs and stress tolerance, yet, they are also interrelated. In addition, PAs are capable of influencing the ion channels, $\mathrm{H}_{2} \mathrm{O}_{2}$ and/or NO-modulated pathways, and the synthesis of plant hormones. This cross-talk between these factors together induce metal/metalloid(s) stress tolerance in plants.

\section{Omics Approaches to Improve Polyamines Actions towards Metals/Metalloid(s) Action}

Systems biology approaches are very useful for improving PAs biosynthesis and their action in the context of the broader genomic, metabolomic, proteomic and transcriptomic network. Not many analyses have been reported so far relating to the use of these approaches to improve PAs actions to enhance metal/metalloid(s) toxicity in plants, but still some interesting findings have been reported. Moreover, the genome sequences availability allows the use of these omics approaches to explore the variation of gene expression on a large genome scale. In this section, we have discussed the potential role of transcriptomics or transgenic approach and proteomics approaches to enhance PAs actions.

\subsection{Transcriptomics}

The accumulation of PAs is generally considered to be a common response of the plant to abiotic stresses, but the cause-effect relationship between the accumulation and protection of PAs remains unclear. To understand the PAs roles in stress tolerance, an effective strategy is to modulate their cellular levels, which has been realized using three different approaches-their exogenous application, PAs synthesis inhibitors use, and overexpression of their biosynthetic genes. Transcriptomics is a very useful approach to understanding PAs induced metal/metalloid(s) tolerance in plants. According to Alcázar et al. [102], studies based on transcriptomics showed different response and regulation of different genes involved in PAs biosynthesis and metabolism. Characterizing these genes can provide a better answer to 'How we can improve PAs induced tolerance in plants in a better and sustainable way?'. Characterization of PAs mutants has provided evidence relating to the involvement of PAs in metal/metalloid(s) stress tolerance [103].

Different studies showed that overexpression of different PAs biosynthetic genes in metal/metalloid (s) sensitive plants was effective in improving stress tolerance (Table 3). The first step catalyzed by the $A D C$ enzyme of PAs biosynthesis to generate Put from Arg. Under metal stress, a metabolic substrate such as $A D C$ or $O D C$ significantly reduced. Nonetheless, Urano et al. [18] showed that the lack of an $A D C$ gene in an Arabidopsis mutant resulted in high sensitivity to stress conditions and showed reduced growth. Likewise, Wen et al. [104] reported that overexpressed SPDS1 in European pear and 
noted that SPDS1 played a very important role in enhancing $\mathrm{Cu}$ stress tolerance. Similar results have been reported under $\mathrm{Cd}, \mathrm{Zn}$, and $\mathrm{Pb}$ stress as well [56].

Table 3. List of transgenic plants encoding PA biosynthetic genes exhibiting high heavy metal tolerance.

\begin{tabular}{ccccc}
\hline PA gene & $\begin{array}{c}\text { Host } \\
\text { plant/organism }\end{array}$ & Transgenic plant & $\begin{array}{c}\text { Targeted metals } \\
\text { (tolerance) }\end{array}$ & Reference \\
\hline SPDS 1 & Apple & European Pear & $\mathrm{Cd}$, Zn, and Pb & Wen et al. [56] \\
\hline SPDS 1 & Apple & European Pear & $\mathrm{Cu}$ stress & Wen et al. [104] \\
\hline SPDS 1 & Apple & European Pear & Cd stress & Wen et al. [105] \\
\hline ADC gene & Agrobacterium & Eggplant & Cd stress & Prabhavathi and Rajam [106] \\
\hline SPDS 1 & Apple & European Pear & Al stress & Wen et al. [107] \\
\hline ALD & & Arabidopsis & Cd and Cu stress & Sunkar et al. [108] \\
\hline
\end{tabular}

Polyamines accumulation under stress condition is mainly influenced by the de novo synthesis of PAs; however, their biosynthesis is primarily controlled and regulated at the transcriptional level. Therefore, understanding the expression pattern of PAs biosynthetic genes under stress conditions would be very useful in enhancing PAs production and their actions. Several types of research have been conducted to examine the steady-state transcriptional levels of PAs biosynthetic genes under different abiotic stress conditions [26] nonetheless under metal stress, hence limited information is available. Among different PAs biosynthetic genes, SPDS, SPMS, SAMDC, and ADC are important, and transcriptomics studies targeted these genes and showed a high level of tolerance $[109,110]$. Among them, SPDS and ADC have been widely studied under different abiotic stress in various plant species. For instance, overexpression of $A D C$ genes in peach and eggplant up-regulated $C d$ tolerance $[106,111]$, which is significantly correlated with high endogenous PAs levels and better antioxidant defense system. Other researchers similarly used transcriptomics approach and noted a high level of tolerance to different abiotic stress in adc eggplant transgenic lines [112,113]. Ornithine $\delta$-aminotransferase $(\delta$-OAT) is a pyridoxal- 5 ' phosphate-dependent enzyme that has been proposed to be involved in the Pro and Arg metabolism. Overexpression of the OsOAT gene in rice showed considerably inhibited oxidative stress by triggering the antioxidant defense system [114]. These results are proving the multifaceted role of PAs in stress amelioration.

\subsection{Proteomics}

Proteomics is a very useful approach as it aimed at systematically sorting and characterizing complex protein structures or proteomes of the genome in different cells at different development stages. This approach also provides information relating to protein localization and protein interaction maps. From last two decades, numerous innovative methods such as protein detection using mass spectrometry, microarray technique, and the yeast two-hybrid system have been developed and used for large scale analysis of proteins, which involved in stress signaling and stress tolerance. Though several groups around the world have used the transcriptomics approach to investigate and to underpin expression level and patterns of different genes relating to PAs induced stress amelioration $[115,116]$; nonetheless, such analysis of mRNA levels has some limitations [117], such as the poor correlation between the expression patterns of mRNAs and their corresponding proteins [118]. Moreover, although the correlation between the expressions of mRNA and corresponding proteins has been identified [119] protein expression is also influenced or regulated at both translational and post-translational levels. Therefore, investigation and exploration of proteins at translational and post-translational levels can provide detailed insights into the response and functional interaction of proteins involved in PAs metabolism and their mode of action in improving metal/metalloid(s) tolerance in plants.

Although several studies, which revealed the use of proteomics approach in studying PAs induced metal/metalloid(s) stress tolerance, are scanty, published studies so far showed the promising role 
of proteomics in studying PAs induced metal/metalloid(s) stress tolerance. Wu et al. [120] used a proteomics approach and identified two proteins relating to SAM, which were involved in increasing Cd stress tolerance in Solanum torvum. Accumulation of SAM synthetase has also been noted in Medicago and rice root under $\mathrm{Cd}$ and As stress, respectively [121,122]. These findings have suggested that changes in the accumulation of SAM and subsequent biosynthesis of PAs caused metal/metalloid(s) stress tolerance [120,122]. Similarly, Yang et al. [123] also used a proteomics approach to study Cd-induced alteration in poplar plants to understand the molecular mechanisms behind Cd-induced toxicity. Under As stress, Ahsan et al. [121] employed a proteomics approach to study the role of proteins in rice root metabolism and found that most of the proteins were related to SAM. Tripathi et al. [116] reviewed and suggested that metal stress-induced ROS production and these ROS act as a signaling molecule and triggered the production of numerous proteins such as SAM, ADC or ODC and increase tolerance in plants. Moreover, targeting these proteins can be useful in improving metal stress in non-tolerant plant species. Similarly, Baig et al. [118] used proteomics approach and showed that $\mathrm{Pb}$ stress tolerance in soybean was associated with a high accumulation of thermospermine synthase ACAULIS5-like protein, this is encoded by ACAULIS5 (ACL5) gene and converts Spd to thermospermidine [124].

In another study, it was found that $\mathrm{Cd}$ tolerance in $\mathrm{Cd}$-treated flax cell was associated with a high accumulation of expression of proteins and enzymes involved in PAs metabolism and SAM biosynthesis, thus high PAs protein levels resulted in high Cd tolerance. Brumbarova et al. [125] analyzed proteome changes in wild type and Fe mutant tomato plants treated with different levels of Fe-stress. They found that Fe mutants accumulated a high amount of non-functional proteins, which were transcription factors involved in Fe-induced changes in gene expression. Moreover, they also noted that tolerance capability of wild type tomato to Fe stress was associated with high expression of enzymes and proteins involved in ROS scavenging and SAM biosynthesis. Likewise, in rice, the concentration of As increased as a result of lipid peroxidation in an As-sensitive cultivar, while the As-tolerant cultivar exhibited high expression levels of SAM and GST, which were involved in improving tolerance to As [121]. Kim and Lee [126] employed proteomics approach and found similar results, and further suggested that targeting such proteins involved in PAs metabolism could be very useful in enhancing PAs induced metal/metalloid(s) tolerance in plants.

\section{Conclusions}

Metals/metalloid(s) toxicity harmfully affects plant growth and development, which results in global yield loss for agriculture. Moreover, toxic metals/metalloid(s) enter into the plant through the root and transferred to the upper parts, which subsequently come into the food chain and become a serious threat for a human being. Hence, it is essential to reduce metal/metalloid(s) from contaminated soil and find stress tolerant cultivars to cope with the future problem of nutritional food security. Polyamines including Put, Spd, and Spm play a significant role in physiology and biochemistry of plant, which confirm normal growth and development. Literature proves that enhanced PAs levels in plants have imperative functions in a wide range of physiological functions under abiotic stress including metals/metalloid(s) toxicity. Polyamines act as ROS scavengers, activate antioxidants, protect biomembranes and biomolecules, and provoke metal chelation under stress condition. In addition, PAs play a signaling role and interact with NO, different hormone, trace elements, and other signaling molecules for developing stress tolerance of the plant. As a result, exogenous applications of PAs getting popularity for enhancing metals/metalloid(s) stress tolerance. Nevertheless, the function of PAs metabolism and biosynthesis in plants for the metals/metalloid(s) stress tolerance has been just commenced to be recognized. Different omics approaches are also supportive to identify the contribution of PAs biosynthetic pathways in conferring stress tolerance. Countless efforts are needed to expose the molecular approaches of PAs induced protective role in stress tolerance. To date, many reports confirm the vital function of PAs under metals/metalloid(s) stress, but further research is required for a comprehensive study about the genes involved stress tolerance. 
Author Contributions: M.H. devised the project, the main conceptual ideas, and proofed the outline. All authors participated in the drafting of this paper as individual subject matter experts in their fields. M.H.M.B.B. and J.A.M. prepared the tables. M.T. and M.H.M.B.B. constructed the figures. M.H., H.A.S.A., M.H.S. and M.F. contributed critically to the improvement and editing of the manuscript. All authors contributed to improving the paper and approved the final manuscript.

Funding: This work received no external funding.

Acknowledgments: The authors greatly acknowledge the Ministry of Education, Culture, Sports, Science and Technology (MEXT) for providing research grants to Mirza Hasanuzzaman, M.H.M. Borhannuddin Bhuyan, and Jubayer Al Mahmud. Mirza Hasanuzzaman is thankful to Sher-e-Bangla Agricultural University Research System for providing a fund for research. We thank Abdul Awal Chowdhury Masud, Nazmin Sultana, and Taufika Islam Anee, Department of Agronomy, Sher-e-Bangla Agricultural University for their critical reading and formatting of the manuscript. H.A.S.A. is thankful to Jouf University for encouraging scientific research and publication. M.H.S. is grateful thanks for Taibah University for facilizing research.

Conflicts of Interest: The authors declare no conflicts of interest.

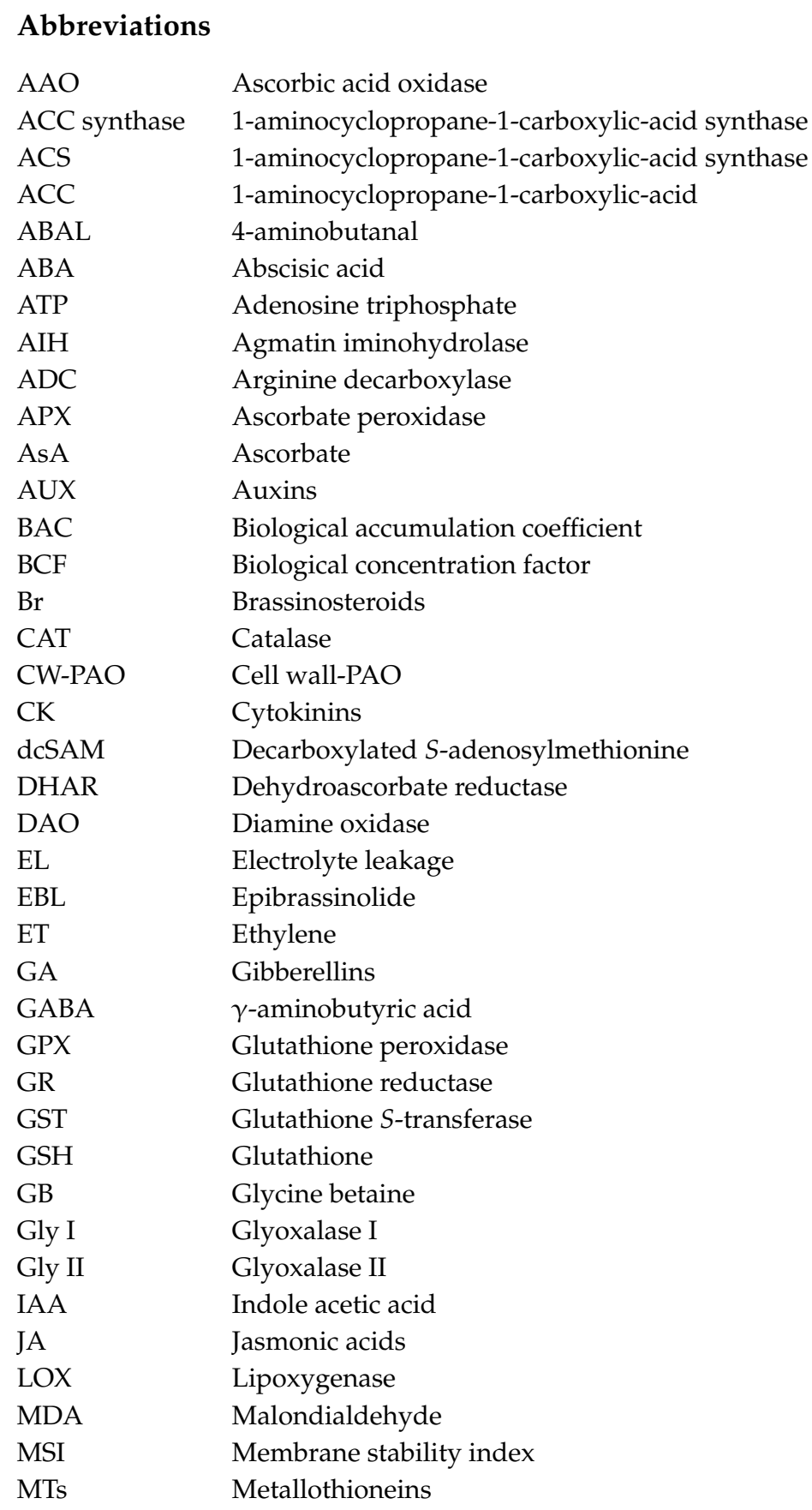




$\begin{array}{ll}\text { MG } & \text { Methylglyoxal } \\ \text { MAPKs } & \text { Mitogen-activated protein kinases } \\ \text { MDHAR } & \text { Monodehydroascorbate reductase } \\ \text { CPA } & \text { N-carbamoylputrescine amidohydrolase } \\ \text { NADPH } & \text { Nicotinamide adenine dinucleotide phosphate } \\ \text { NR } & \text { Nitrate reductase } \\ \text { NOS } & \text { NO synthase } \\ \text { OTC } & \text { Ornithine transcarbamoylase } \\ \delta \text {-OAT } & \text { Ornithine } \delta \text {-aminotransferase } \\ \text { ODC } & \text { Ortinine decarboxylase } \\ \text { PC } & \text { Phytochelatins } \\ \text { PAs } & \text { Polyamines } \\ \text { PPO } & \text { Polyphenol oxidase } \\ \text { Pro } & \text { Proline } \\ \text { Put } & \text { Putrescine } \\ \text { PDH } & \text { Pyrroline dehydrogenase } \\ \text { ROS } & \text { Reactive oxygen species } \\ \text { RWC } & \text { Relative water content } \\ \text { SAMDC } & \text { S-adenosylmethionine decarboxylase } \\ \text { SAM } & \text { S-adenosylmethionine } \\ \text { SA } & \text { Salicylic acid } \\ \text { SNP } & \text { Sodium nitroprusside } \\ \text { SPDS } & \text { Spermidine synthase } \\ \text { Spd } & \text { Spermidine } \\ \text { SPMS } & \text { Spermine synthase } \\ \text { Spm } & \text { Spermine } \\ \text { SOD } & \text { Superoxide dismutase } \\ \text { TBARS } & \text { Thiobarbituric acid } \\ \text { TF } & \text { Translocation factor } \\ & \end{array}$

\section{References}

1. Nahar, K.; Hasanuzzaman, M.; Alam, M.M.; Rahman, A.; Suzuki, T.; Fujita, M. Polyamine and nitric oxide crosstalk: Antagonistic effects on cadmium toxicity in mung bean plants through upregulating the metal detoxification, antioxidant defense and methylglyoxal detoxification systems. Ecotoxicol. Environ. Saf. 2016, 126, 245-255. [CrossRef] [PubMed]

2. Singh, P.; Basu, S.; Kumar, G. Polyamines metabolism: A way ahead for abiotic stress tolerance in crop plants. In Biochemical, Physiological and Molecular Avenues for Combating Abiotic Stress Tolerance in Plants; Wani, S.H., Ed.; Academic Press: London, UK, 2018; pp. 39-55.

3. Chen, D.; Shao, Q.; Yin, L.; Younis, A.; Zheng, B. Polyamine function in plants: Metabolism, regulation on development, and roles in abiotic stress responses. Front. Plant Sci. 2019, 9, 1945. [CrossRef] [PubMed]

4. Minois, N. Molecular basis of the 'anti-aging' effect of spermidine and other natural polyamines-A mini-review. Gerontology 2014, 60, 319-326. [CrossRef] [PubMed]

5. Benavides, M.P.; Groppa, M.D.; Recalde, L.; Verstraeten, S.V. Effects of polyamines on cadmium-and copper-mediated alterations in wheat (Triticum aestivum L.) and sunflower (Helianthus annuus L.) seedling membrane fluidity. Arch. Biochem. Biophys. 2018, 654, 27-39. [CrossRef] [PubMed]

6. Groppa, M.D.; Benavides, M.P.; Tomaro, M.L. Polyamine metabolism in sunflower and wheat leaf discs under cadmium or copper stress. Plant Sci. 2003, 164, 293-299. [CrossRef]

7. Fahad, S.; Rehman, A.; Shahzad, B.; Tanveer, M.; Saud, S.; Kamran, M.; Ihtisham, M.; Khan, S.U.; Turan, V.V.; ur Rahman, M.H. Rice responses and tolerance to metal/metalloid toxicity. In Advances in Rice Research for Abiotic Stress Tolerance; Hasanuzzaman, M., Fujita, M., Nahar, K., Biswas, J.K., Eds.; Eds.; Woodhead Publishing: London, UK, 2019; pp. 299-312. 
8. Paul, S.; Banerjee, A.; Roychoudhury, A. Role of polyamines in mediating antioxidant defense and epigenetic regulation in plants exposed to heavy metal toxicity. In Plants Under Metal and Metalloid Stress; Hasanuzzaman, M., Nahar, K., Fujita, M., Eds.; Eds.; Springer: Singapore, 2018; pp. 229-247.

9. Tajti, J.; Janda, T.; Majláth, E.; Szalai, G.; Pál, M. Comparative study on the effects of putrescine and spermidine pre-treatment on cadmium stress in wheat. Ecotoxicol. Environ. Saf. 2018, 148, 546-554. [CrossRef]

10. Gong, X.; Liu, Y.; Huang, D.; Zeng, G.; Liu, S.; Tang, H.; Zhou, L.; Hu, X.; Zhou, Y.; Tan, X. Effects of exogenous calcium and spermidine on cadmium stress moderation and metal accumulation in Boehmeria nivea (L.) Gaudich. Environ. Sci. Pollut. Res. 2016, 23, 8699-8708. [CrossRef]

11. Rady, M.M.; Hemida, K.A. Modulation of cadmium toxicity and enhancing cadmium-tolerance in wheat seedlings by exogenous application of polyamines. Ecotoxicol. Environ. Saf. 2015, 119, 178-185. [CrossRef]

12. Taie, H.A.; El-Yazal, M.A.S.; Ahmed, S.M.; Rady, M.M. Polyamines modulate growth, antioxidant activity, and genomic DNA in heavy metal-stressed wheat plant. Environ. Sci. Pollut. Res. 2019. [CrossRef]

13. Alcázar, R.; Cuevas, J.C.; Patrón, M.; Altabella, T.; Tiburcio, A.F. Abscisic acid modulates polyamine metabolism under water stress in Arabidopsis thaliana. Physiol. Plant 2006, 128, 448-455. [CrossRef]

14. Hanfrey, C.; Sommer, S.; Mayer, M.J.; Burtin, D.; Michael, A.J. Arabidopsis polyamine biosynthesis: Absence of ornithine decarboxylase and the mechanism of arginine decarboxylase activity. Plant J. 2001, 27, 551-560. [CrossRef] [PubMed]

15. Alcázar, R.; García-Martínez, J.L.; Cuevas, J.C.; Tiburcio, A.F.; Altabella, T. Overexpression of ADC2 in Arabidopsis induces dwarfism and late-flowering through GA deficiency. Plant J. 2005, 43, 425-436. [CrossRef] [PubMed]

16. Hanzawa, Y.; Takahashi, T.; Michael, A.J.; Burtin, D.; Long, D.; Pineiro, M.; Coupland, G.; Komeda, Y. ACAULIS5, an Arabidopsis gene required for stem elongation, encodes a spermine synthase. EMBO J. 2000, 19, 4248-4256. [CrossRef] [PubMed]

17. Panicot, M.; Minguet, E.G.; Ferrando, A.; Alca'zar, R.; Bla’́zquez, M.A.; Carbonell, J.; Altabella, T.; Koncz, C.; Tiburcio, A.F. A polyamine metabolon involving aminopropyl transferases complexes in Arabidopsis. Plant Cell 2002, 14, 2539-2551. [CrossRef] [PubMed]

18. Urano, K.; Yoshiba, Y.; Nanjo, T.; Ito, T.; Yamaguchi-Shinozaki, K.; Shinozaki, K. Arabidopsis stress-inducible gene for arginine decarboxylase $A t A D C 2$ is required for accumulation of putrescine in salt tolerance. Biochem. Biophys. Res. Comm. 2004, 313, 369-375. [CrossRef]

19. Kakkar, R.K.; Sawhney, V.K. Polyamine research in plants. A changing perspective. Physiol. Plant 2002, 116, 281-292. [CrossRef]

20. Majumdar, R.; Shao, L.; Minocha, R.; Long, S.; Minocha, S.C. Ornithine: The overlooked molecule in regulation of polyamine metabolism. Plant Cell Physiol. 2013, 54, 990-1004. [CrossRef]

21. Kuthanová, A.; Gemperlová, L.; Zelenková, S.; Eder, J.; Machácková, I.; Opatrny, Z.; Cvikrová, M. Cytological changes and alterations in polyamine contents induced by cadmium in tobacco BY-2 cells. Plant Physiol. Biochem. 2004, 42, 149-156. [CrossRef]

22. Choudhary, A.; Singh, R.P. Cadmium-induced changes in diamine oxidase activity and polyamine levels in Vigna radiata Wilczek seedlings. J. Plant Physiol. 2000, 156, 704-710. [CrossRef]

23. Chen, L.; Wang, L.; Chen, F.; Korpelainen, H.; Li, C. The effects of exogenous putrescine on sex-specific responses of Populus cathayana to copper stress. Ecotoxicol. Environ. Saf. 2013, 97, 94-102. [CrossRef]

24. Podlešáková, K.; Ugena, L.; Spíchal, L.; Doležal, K.; De Diego, N. Phytohormones and polyamines regulate plant stress responses by altering GABA pathway. New Biotechnol. 2019, 48, 53-65. [CrossRef] [PubMed]

25. Hasanuzzaman, M.; Nahar, K.; Fujita, M. Regulatory role of polyamines in growth, development and abiotic stress tolerance in plants. In Plant Adaptation to Environmental Change: Significance of Amino Acids and their Derivatives; Anjum, N.A., Gill, S.S., Gill, R., Eds.; CABI: Wallingford, UK, 2014; pp. 157-193.

26. Liu, J.H.; Wang, W.; Wu, H.; Gong, X.; Moriguchi, T. Polyamines function in stress tolerance: From synthesis to regulation. Front. Plant Sci. 2015, 6, 827. [CrossRef] [PubMed]

27. Shahid, M.A.; Balal, R.M.; Khan, N.; Rossi, L.; Rathinasabapathi, B.; Liu, G.; Khan, J.; Cámara-Zapata, J.M.; Martínez-Nicolas, J.J.; Garcia-Sanchez, F. Polyamines provide new insights into the biochemical basis of Cr-tolerance in Kinnow mandarin grafted on diploid and double-diploid rootstocks. Environ. Exp. Bot. 2018, 156, 248-260. [CrossRef] 
28. Rady, M.M.; Ahmed, S.M.; El-Yazal, M.A.S.; Taie, H.A. Alleviation of cadmium stress in wheat by polyamines. In Cadmium Tolerance in Plants: Agronomic, Molecular, Signaling, and Omic Approaches; Hasanuzzaman, M., Prasad, M., Nahar, K., Eds.; Elsevier: London, UK, 2019; pp. 463-496.

29. Yu, Y.; Zhou, W.; Zhou, K.; Liu, W.; Liang, X.; Chen, Y.; Dasheng, S.; Xianyong, L. Polyamines modulate aluminum-induced oxidative stress differently by inducing or reducing $\mathrm{H}_{2} \mathrm{O}_{2}$ production in wheat. Chemosphere 2018, 212, 645-653. [CrossRef] [PubMed]

30. Howladar, S.M.; Al-Robai, S.A.; Al-Zahrani, F.S.; Howladar, M.M.; Aldhebiani, A.Y. Silicon and its application method effects on modulation of cadmium stress responses in Triticum aestivum (L.) through improving the antioxidative defense system and polyamine gene expression. Ecotoxicol. Environ. Saf. 2018, 159, 143-152. [CrossRef] [PubMed]

31. Rady, M.M.; El-Yazal, M.A.S.; Taie, H.A.A.; Ahmed, S.M. Response of wheat growth and productivity to exogenous polyamines under lead stress. J. Crop Sci. Biotechnol. 2016, 19, 363-371. [CrossRef]

32. Mir, B.A.; Khan, T.A.; Fariduddin, Q. 24-epibrassinolide and spermidine modulate photosynthesis and antioxidant systems in Vigna radiata under salt and zinc stress. Int. J. Adv. Res. 2015, 3, 592-608.

33. Piotrowska-Niczyporuk, A.; Bajguz, A.; Zambryzycka, E.; Godlewska-Zylkiewicz, B. Phytohormones as regulators of heavy metal biosorption and toxicity in green alga Chlorella vulgaris (Chlorophyceae). Plant Physiol. Biochem. 2012, 52, 52-65. [CrossRef]

34. Choudhary, S.P.; Kanwar, M.; Bhardwaj, R.; Yu, J.Q.; Tran, L.S.P. Chromium stress mitigation by polyamine-brassinosteroid application involves phytohormonal and physiological strategies in Raphanus sativus L. PLoS ONE 2012, 7, e33210. [CrossRef]

35. Tang, C.; Zhang, R.; Hu, X.; Song, J.; Li, B.; Ou, D.; Hu, X.; Zhao, Y. Exogenous spermidine elevating cadmium tolerance in Salix matsudana involves cadmium detoxification and antioxidant defense. Int. J. Phytorem. 2019, 21, 305-315. [CrossRef]

36. Yang, H.; Shi, G.; Wang, H.; Xu, Q. Involvement of polyamines in adaptation of Potamogeton crispus L. to cadmium stress. Aquat. Toxicol. 2010, 100, 282-288. [CrossRef] [PubMed]

37. Groppa, M.D.; Tomaro, M.L.; Benavides, M.P. Polyamines as protectors against cadmium or copper-induced oxidative damage in sunflower leaf discs. Plant Sci. 2001, 161, 481-488. [CrossRef]

38. Hsu, Y.T.; Kao, C.H. Cadmium-induced oxidative damage in rice leaves is reduced by polyamines. Plant Soil 2007, 291, 27-37. [CrossRef]

39. Groppa, M.D.; Tomaro, M.L.; Benavides, M.P. Polyamines and heavy metal stress: The antioxidant behavior of spermine in cadmium and copper-treated wheat leaves. Biometals 2007, 20, 185-195. [CrossRef] [PubMed]

40. Anjum, N.A.; Hasanuzzaman, M.; Hossain, M.A.; Thangavel, P.; Roychoudhury, A.; Gill, S.S.; Rodrigo, M.A.M.; Adam, V.; Fujita, M.; Kizek, R.; et al. Jacks of metal/metalloid chelation trade in plants-an overview. Front. Plant Sci. 2015, 6, 192. [CrossRef] [PubMed]

41. Amist, N.; Singh, N.B. Responses of enzymes involved in proline biosynthesis and degradation in wheat seedlings under stress. Allelopathy J. 2017, 42, 195-205. [CrossRef]

42. Shu, S.; Yuan, L.Y.; Guo, S.R.; Sun, J.; Liu, C.J. Effects of exogenous spermidine on photosynthesis, xanthophyll cycle and endogenous polyamines in cucumber seedlings exposed to salinity. Afr. J. Biotechnol. 2012, 11, 6064-6074.

43. Balal, R.M.; Shahid, M.A.; Javaid, M.M.; Iqbal, Z.; Liu, G.D.; Zotarelli, L.; Khan, N. Chitosan alleviates phytotoxicity caused by boron through augmented polyamine metabolism and antioxidant activities and reduced boron concentration in Cucumis sativus L. Acta Physiol. Plant 2016, 39, 31-36. [CrossRef]

44. Kumar, M.; Kuzhiumparambil, U.; Ralph, P.; Contreras-Porcia, L. Polyamines: Stress metabolite in marine macrophytes. In Algal Green Chemistry, Recent Progress in Biotechnology; Rastogi, R.P., Pandey, A., Eds.; Elsevier: Amsterdam, The Netherlands, 2017; pp. 243-255.

45. Ghabriche, R.; Ghnaya, T.; Zaier, H.; Baioui, R.; Vromman, D.; Abdelly, C.; Lutts, S. Polyamine and tyramine involvement in $\mathrm{NaCl}$-induced improvement of $\mathrm{Cd}$ resistance in the halophyte Inula chrithmoides $\mathrm{L}$. J. Plant Physiol. 2017, 216, 136-144. [CrossRef]

46. Baniasadi, F.; Saffari, V.R.; Moud, A.A.M. Physiological and growth responses of Calendula officinalis L. plants to the interaction effects of polyamines and salt stress. Sci. Hortic. 2018, 234, 312-317. [CrossRef]

47. Hassan, F.A.S.; Ali, E.F.; Alamer, K.H. Exogenous application of polyamines alleviates water stress-induced oxidative stress of Rosa damascena Miller var. Trigintipetala Dieck. South Afr. J. Bot. 2018, 116, 96-102. [CrossRef] 
48. Groppa, M.D.; Benavides, M.P. Polyamines and abiotic stress: Recent advances. Amino Acids 2008, 34, 35-45. [CrossRef] [PubMed]

49. Løvaas, E. Antioxidative and metal-chelating effects of polyamines. Adv. Pharmacol. 1996, 38, 119-149.

50. Velikova, V.; Yordanov, I.; Edreva, A. Oxidative stress and some antioxidant systems in acid rain-treated bean plants protective role of endogenous polyamines. Plant Sci. 2000, 151, 59-66. [CrossRef]

51. Sánchez-Rodríguez, E.; Romero, L.; Ruiz, J.M. Accumulation of free polyamines enhances the antioxidant response in fruits of grafted tomato plants under water stress. J. Plant Physiol. 2016, 190, 72-78. [CrossRef] [PubMed]

52. Clemens, S. Molecular mechanisms of plant metal tolerance and homeostasis. Planta 2001, 212, 475-486. [CrossRef] [PubMed]

53. Hassan, Z.; Aarts, M.G.M. Opportunities and feasibilities for biotechnological improvement of Zn, Cd or Ni tolerance and accumulation in plants. Environ. Exp. Bot. 2011, 72, 53-63. [CrossRef]

54. Mahmud, J.A.; Hasanuzzaman, M.; Nahar, K.; Bhuyan, M.B.; Fujita, M. Insights into citric acid-induced cadmium tolerance and phytoremediation in Brassica juncea L.: Coordinated functions of metal chelation, antioxidant defense and glyoxalase systems. Ecotoxicol. Environ. Saf. 2018, 147, 990-1001. [CrossRef]

55. Lv, Y.; Deng, X.; Quan, L.; Xia, Y.; Shen, Z. Metallothioneins BcMT1 and BcMT2 from Brassica campestris enhance tolerance to cadmium and copper and decrease production of reactive oxygen species in Arabidopsis thaliana. Plant Soil 2013, 367, 507-519. [CrossRef]

56. Wen, X.P.; Ban, Y.; Inoue, H.; Matsuda, N.; Moriguchi, T. Spermidine levels are implicated in heavy metal tolerance in a spermidine synthase overexpressing transgenic European pear by exerting antioxidant activities. Transgenic Res. 2010, 19, 91-103. [CrossRef]

57. Flink, L.; Pettijohn, D.E. Polyamines stabilize DNA folds. Nature 1975, 253, 62-63. [CrossRef] [PubMed]

58. Pál, M.; Csávás, G.; Szalai, G.; Oláh, T.; Khalil, R.; Yordanova, R.; Gell, G.; Birinyi, Z.; Németh, E.; Janda, T. Polyamines may influence phytochelatin synthesis during Cd stress in rice. J. Hazard. Mater. 2017, 340, 272-280. [CrossRef] [PubMed]

59. Ali, H.; Khan, E.; Sajad, M.A. Phytoremediation of heavy metals—concepts and applications. Chemosphere 2013, 91, 869-881. [CrossRef] [PubMed]

60. Abhilash, P.C.; Powell, J.R.; Singh, H.B.; Singh, B.K. Plant-microbe interactions: Novel applications for exploitation in multipurpose remediation technologies. Trends Biotechnol. 2012, 30, 416-420. [CrossRef] [PubMed]

61. Keymirov, M.A. Water Purification of Ions of Heavy Metals by Montmorillonite Modified with Polyamine. J. Water Chem. Technol. 2018, 40, 320-326. [CrossRef]

62. Nahar, K.; Rahman, M.; Hasanuzzaman, M.; Alam, M.M.; Rahman, A.; Suzuki, T.; Fujita, M. Physiological and biochemical mechanisms of spermine-induced cadmium stress tolerance in mung bean (Vigna radiata $\mathrm{L}$.) seedlings. Environ Sci. Pollut. Res. 2016, 23, 21206-21218. [CrossRef] [PubMed]

63. Shevyakova, N.I.; Il'ina, E.N.; Kuznetsov, V.V. Polyamines increase plant potential for phytoremediation of soils polluted with heavy metals. Doklady Biol. Sci. 2008, 423, 457-460. [CrossRef]

64. Soudek, P.; Ursu, M.; Petrová, S.; Vaněk, T. Improving crop tolerance to heavy metalstress by polyamine application. Food Chem. 2016, 213, 223-229. [CrossRef]

65. Guo, Z.; Tan, J.; Zhuo, C.; Wang, C.; Xiang, B.; Wang, Z. Abscisic acid $\mathrm{H}_{2} \mathrm{O}_{2}$ and nitric oxide interactions mediated cold-induced $S$-adenosyl methionine synthetase in Medicago sativa subsp. falcata that confers cold tolerance through up-regulating polyamine oxidation. Plant Biotechnol. J. 2014, 12, 601-612. [CrossRef]

66. Gao, H.J.; Yang, H.Q.; Wang, J.X. Arginine metabolism in roots and leaves of apple (Malus domestica Borkh.): The tissue-specific formation of both nitric oxide and polyamines. Sci. Hortic. 2009, 119, 147-152. [CrossRef]

67. Shi, H.; Chan, Z. Improvement of plant abiotic stress tolerance through modulation of the polyamine pathway. J. Integr. Plant Biol. 2014, 56, 114-121. [CrossRef] [PubMed]

68. Tun, N.N.; Santa-Catarina, C.; Begum, T.; Silveira, V.; Handro, W.; Floh, E.I.S.; Scherer, G.F. Polyamines induce rapid biosynthesis of nitric oxide (NO) in Arabidopsis thaliana seedlings. Plant Cell Physiol. 2006, 47, 346-354. [CrossRef] [PubMed]

69. Wimalasekera, R.; Tebartz, F.; Scherer, G.F. Polyamines, polyamine oxidases and nitric oxide in development, abiotic and biotic stresses. Plant Sci. 2011, 181, 593-603. [CrossRef] [PubMed]

70. Saha, J.; Brauer, E.K.; Sengupta, A.; Popescu, S.C.; Gupta, K.; Gupta, B. Polyamines as redox homeostasis regulators during salt stress in plants. Front. Environ. Sci. 2015, 3, 21. [CrossRef] 
71. Pottosin, I.; Velarde-Buendía, A.M.; Bose, J.; Fuglsang, A.T.; Shabala, S. Polyamines cause plasma membrane depolarization, activate $\mathrm{Ca}^{2+}$, and modulate $\mathrm{H}^{+}$-ATPase pump activity in pea roots. J. Exp. Bot. 2014, 65, 2463-2472. [CrossRef] [PubMed]

72. Moschou, P.N.; Paschalidis, K.A.; Delis, I.D.; Andriopoulou, A.H.; Lagiotis, G.D.; Yakoumakis, D.I.; Roubelakis-Angelakis, K.A. Spermidine exodus and oxidation in the apoplast induced by abiotic stress is responsible for $\mathrm{H}_{2} \mathrm{O}_{2}$ signatures that direct tolerance responses in tobacco. Plant Cell 2008, 20, 1708-1724. [CrossRef] [PubMed]

73. Andronis, E.A.; Moschou, P.N.; Toumi, I.; Roubelakis-Angelakis, K.A. Peroxisomal polyamine oxidase and NADPH-oxidase cross-talk for ROS homeostasis which affects respiration rate in Arabidopsis thaliana. Front. Plant Sci. 2014, 5, 132. [CrossRef] [PubMed]

74. Kabała, K.; Zboińska, M.; Głowiak, D.; Reda, M.; Jakubowska, D.; Janicka, M. Interaction between the signaling molecules hydrogen sulfide and hydrogen peroxide and their role in vacuolar $\mathrm{H}^{+}$-ATPase regulation in cadmium-stressed cucumber roots. Physiol. Plant 2018. [CrossRef]

75. Yang, R.; Guo, Q.; Gu, Z. GABA shunt and polyamine degradation pathway on $\gamma$-aminobutyric acid accumulation in germinating fava bean (Vicia faba L.) under hypoxia. Food Chem. 2013, 136, 152-159. [CrossRef]

76. Hatmi, S.; Gruau, C.; Trotel-Aziz, P.; Villaume, S.; Rabenoelina, F.; Baillieul, F.; Eullaffroy, P.; Clément, C.; Ferchichi, A.; Aziz, A. Drought stress tolerance in grapevine involves activation of polyamine oxidation contributing to improved immune response and low susceptibility to Botrytis cinerea. J. Exp. Bot. 2015, 66, 775-787. [CrossRef]

77. Al-Quraan, N.A. GABA shunt deficiencies and accumulation of reactive oxygen species under UV treatments: Insight from Arabidopsis thaliana calmodulin mutants. Acta Physiol. Plant 2015, 37, 1-11. [CrossRef]

78. Mahmud, J.A.; Hasanuzzaman, M.; Nahar, K.; Rahman, A.; Hossain, M.S.; Fujita, M. $\gamma$-aminobutyric acid (GABA) confers chromium stress tolerance in Brassica juncea L. by modulating the antioxidant defense and glyoxalase systems. Ecotoxicology 2017, 26, 675-690. [CrossRef] [PubMed]

79. Song, H.; Xu, X.; Wang, H.; Wang, H.; Tao, Y. Exogenous $\gamma$-aminobutyric acid alleviates oxidative damage caused by aluminium and proton stresses on barley seedlings. J. Sci. Food Agric. 2010, 90, 1410-1416. [CrossRef] [PubMed]

80. Shi, S.Q.; Shi, Z.; Jiang, Z.P.; Qi, L.W.; Sun, X.M.; Li, C.X.; Liu, J.F.; Xiao, W.F.; Zhang, S.G. Effects of exogenous GABA on gene expression of Caragana intermedia roots under $\mathrm{NaCl}$ stress: Regulatory roles for $\mathrm{H}_{2} \mathrm{O}_{2}$ and ethylene production. Plant Cell Environ 2010, 33, 149-162. [CrossRef] [PubMed]

81. Wang, C.; Fan, L.; Gao, H.; Wu, X.; Li, J.; Lv, G.; Gong, B. Polyamine biosynthesis and degradation are modulated by exogenous gamma-aminobutyric acid in root-zone hypoxia-stressed melon roots. Plant Physiol. Biochem. 2014, 82, 17-26. [CrossRef]

82. Hu, X.; Xu, Z.; Xu, W.; Li, J.; Zhao, N.; Zhou, Y. Application of $\gamma$-amino butyric acid demonstrates a protective role of polyamine and GABA metabolism in muskmelon seedlings under $\mathrm{Ca}\left(\mathrm{NO}_{3}\right)_{2}$ stress. Plant Physiol. Biochem. 2015, 92, 1-10. [CrossRef] [PubMed]

83. Zhang, L.; Becker, D.F. Connecting proline metabolism and signaling pathways in plant senescence. Front. Plant Sci. 2015, 6, 552. [CrossRef]

84. Seifikalhor, M.; Aliniaeifard, S.; Hassani, B.; Niknam, V.; Lastochkina, O. Diverse role of $\gamma$-aminobutyric acid in dynamic plant cell responses. Plant Cell Rep. 2019. [CrossRef]

85. Nahar, K.; Hasanuzzaman, M.; Suzuki, T.; Fujita, M. Polyamines-induced aluminum tolerance in mung bean: A study on antioxidant defense and methylglyoxal detoxification systems. Ecotoxicology 2017, 26, 58-73. [CrossRef]

86. Cvikrová, M.; Gemperlová, L.; Martincová, O.; Vanková, R. Effect of drought and combined drought and heat stress on polyamine metabolism in proline-over-producing tobacco plants. Plant Physiol. Biochem. 2013, 73, 7-15. [CrossRef]

87. Agami, R.A. Pre-soaking in indole-3-acetic acid or spermidine enhances copper tolerance in wheat seedlings. South. Afr. J. Bot. 2016, 104, 167-174. [CrossRef]

88. Cui, X.; Ge, C.; Wang, R.; Wang, H.; Chen, W.; Fu, Z.; Jiang, X.; Li, J.; Wang, Y. The BUD2 mutation affects plant architecture through altering cytokinin and auxin responses in Arabidopsis. Cell Res. 2010, 20, 576-586. [CrossRef] [PubMed] 
89. Yin, L.; Wang, S.; Liu, P.; Wang, W.; Cao, D.; Deng, X.; Zhang, S. Silicon-mediated changes in polyamine and 1-aminocyclopropane-1-carboxylic acid are involved in silicon-induced drought resistance in Sorghum bicolor $\mathrm{L}$. Plant Physiol. Biochem. 2014, 80, 268-277. [CrossRef] [PubMed]

90. Takahashi, Y.; Cong, R.; Sagor, G.H.M.; Niitsu, M.; Berberich, T.; Kusano, T. Characterization of five polyamine oxidase isoforms in Arabidopsis thaliana. Plant Cell Rep. 2010, 29, 955-965. [CrossRef] [PubMed]

91. Arc, E.; Sechet, J.; Corbineau, F.; Rajjou, L.; Marion-Poll, A. ABA crosstalk with ethylene and nitric oxide in seed dormancy and germination. Front. Plant Sci. 2013, 4, 63. [CrossRef] [PubMed]

92. Manjunatha, G.; Gupta, K.J.; Lokesh, V.; Mur, L.A.; Neelwarne, B. Nitric oxide counters ethylene effects on ripening fruits. Plant Signal. Behav. 2012, 7, 476-483. [CrossRef] [PubMed]

93. Asgher, M.; Khan, M.I.R.; Anjum, N.A.; Verma, S.; Vyas, D.; Per, T.S.; Masood, A.; Khan, N.A. Ethylene and polyamines in counteracting heavy metal phytotoxicity: A crosstalk perspective. J. Plant Growth Regul. 2018, 37, 1050-1065. [CrossRef]

94. Chmielowska-Bakk, J.; Lefèvre, I.; Lutts, S.; Deckert, J. Short term signaling responses in roots of young soybean seedlings exposed to cadmium stress. J. Plant Physiol. 2013, 170, 1585-1594. [CrossRef]

95. Alet, A.I.; Sanchez, D.H.; Cuevas, J.C.; del Valle, S.; Altabella, T.; Tiburcio, A.F.; Marco, F.; Ferrando, A.; Espasandín, F.D.; González, M.E.; et al. Putrescine accumulation in Arabidopsis thaliana transgenic lines enhances tolerance to dehydration and freezing stress. Plant Signal. Behav. 2011, 6, 278-286. [CrossRef]

96. Espasandin, F.D.; Maiale, S.J.; Calzadilla, P.; Ruiz, O.A.; Sansberro, P.A. Transcriptional regulation of 9-cis-epoxycarotenoid dioxygenase (NCED) gene by putrescine accumulation positively modulates ABA synthesis and drought tolerance in Lotus tenuis plants. Plant Physiol. Biochem. 2014, 76, 29-35. [CrossRef]

97. Cuevas, J.C.; López-Cobollo, R.; Alcázar, R.; Zarza, X.; Koncz, C.; Altabella, T.; Salinas, J.; Tiburcio, A.F.; Ferrando, A. Putrescine is involved in Arabidopsis freezing tolerance and cold acclimation by regulating abscisic acid levels in response to low temperature. Plant Physiol. 2008, 148, 1094-1105. [CrossRef] [PubMed]

98. Keunen, E.; Schellingen, K.; Vangronsveld, J.; Cuypers, A. Ethylene and metal stress: Small molecule, big impact. Front. Plant Sci. 2016, 7, 23. [CrossRef] [PubMed]

99. Szepesi, Á.; Gémes, K.; Orosz, G.; Peto, A.; Takács, Z.; Vorák, M.; Tari, I. Interaction between salicylic acid and polyamines and their possible roles in tomato hardening processes. Acta Biol. Szegediensis 2011, 55, 165-166.

100. Baronas, V.A.; Kurata, H.T. Inward rectifiers and their regulation by endogenous polyamines. Front. Physiol. 2014, 5, 325. [CrossRef] [PubMed]

101. Liu, T.; Kim, D.W.; Niitsu, M.; Berberich, T.; Kusano, T. Oryza sativa polyamine oxidase 1 back-converts tetraamines, spermine and thermospermine, to spermidine. Plant Cell Rep. 2014, 33, 143-151. [CrossRef] [PubMed]

102. Alcázar, R.; Marco, F.; Cuevas, J.C.; Patron, M.; Ferrando, A.; Carrasco, P.; Tiburcio, A.F.; Altabella, T. Involvement of polyamines in plant response to abiotic stress. Biotechnol. Lett. 2006, 28, 1867-1876. [CrossRef] [PubMed]

103. Gill, S.S.; Tuteja, N. Polyamines and abiotic stress tolerance in plants. Plant Signal. Behav. 2010, 5, $26-33$. [CrossRef] [PubMed]

104. Wen, X.P.; Pang, X.M.; Matsuda, N.; Kita, M.; Inoue, H.; Hao, Y.J.; Honda, C.; Moriguchi, T. Over-expression of the apple spermidine synthase gene in pear confers multiple abiotic stress tolerance by altering polyamine titers. Transgenic Res. 2008, 17, 251-263. [CrossRef] [PubMed]

105. Wen, X.P.; Ban, Y.; Pang, X.M.; Moriguchi, T. Identification of differentially-expressed genes potentially related to stress tolerance in a transgenic line of European pear over-expressing an apple spermidine synthase gene (MdSPDS1). J. Hort. Sci. Biotechnol. 2011, 86, 146-152. [CrossRef]

106. Prabhavathi, V.R.; Rajam, M.V. Polyamine accumulation in transgenic eggplant enhances tolerance to multiple abiotic stresses and fungal resistance. Plant Biotechnol. 2007, 24, 273-282. [CrossRef]

107. Wen, X.P.; Ban, Y.; Inoue, H.; Matsuda, N.; Moriguchi, T. Aluminum tolerance in a spermidine synthase-overexpressing transgenic European pear is correlated with the enhanced level of spermidine via alleviating oxidative status. Environ. Exp. Bot. 2009, 66, 471-478. [CrossRef]

108. Sunkar, R.; Bartels, D.; Kirch, H.H. Overexpression of a stress-inducible aldehyde dehydrogenase gene from Arabidopsis thaliana in transgenic plants improves stress tolerance. Plant J. 2003, 35, 452-464. [CrossRef] [PubMed]

109. Liu, J.H.; Kitashiba, H.; Wang, J.; Ban, Y.; Moriguchi, T. Polyamines and their ability to provide environmental stress tolerance to plants. Plant Biotechnol. 2007, 24, 117-126. [CrossRef] 
110. Wang, J.; Sun, P.P.; Chen, C.L.; Wang, Y.; Fu, X.Z.; Liu, J.H. An arginine decarboxylase gene PtADC from Poncirus trifoliata confers abiotic stress tolerance and promotes primary root growth in Arabidopsis. J. Exp. Bot. 2011, 62, 2899-2914. [CrossRef] [PubMed]

111. Liu, J.H.; Ban, Y.; Wen, X.P.; Nakajima, I.; Moriguchi, T. Molecular cloning and expression analysis of an arginine decarboxylase gene from peach (Prunus persica). Gene 2009, 429, 10-17. [CrossRef]

112. Das, K.C.; Mishra, H.P. Hydroxyl radical scavenging and singlet oxygen quenching properties of polyamines. Mol. Cell. Biochem. 2004, 262, 127-133. [CrossRef] [PubMed]

113. Kumar, S.V.; Sharma, M.L.; Rajam, M.V. Polyamine biosynthetic pathway as a novel target for potential applications in plant biotechnology. Physiol. Mol. Biol. Plants 2006, 12, 13-28.

114. You, J.; Hu, H.; Xiong, L. An ornithine $\delta$-aminotransferase gene OsOAT confers drought and oxidative stress tolerance in rice. Plant Sci. 2012, 197, 59-69. [CrossRef]

115. Chakrabarty, D.; Trivedi, P.K.; Misra, P.; Tiwari, M.; Shri, M.; Shukla, D.; Kumar, S.; Rai, A.; Pandey, A.; Nigam, D.; et al. Comparative transcriptome analysis of arsenate and arsenite stresses in rice seedlings. Chemosphere 2009, 74, 688-702. [CrossRef]

116. Tripathi, R.D.; Tripathi, P.; Dwivedi, S.; Dubey, S.; Chakrabarty, D. Arsenomics: Omics of arsenic metabolism in plants. Front. Physiol. 2012, 3, 275. [CrossRef]

117. Rose, J.C.; Bashir, S.; Giovannoni, J.J.; Jahn, M.M.; Saravanan, R.S. Tackling the plant proteome: Practical approaches, hurdles and experimental tools. Plant J. 2004, 39, 715-733. [CrossRef] [PubMed]

118. Baig, M.A.; Ahmad, J.; Bagheri, R.; Ali, A.A.; Al-Huqail, A.A.; Ibrahim, M.M.; Qureshi, M.I. Proteomic and ecophysiological responses of soybean (Glycine max L.) root nodules to $\mathrm{Pb}$ and hg stress. BMC Plant Biol. 2018, 18, 283. [CrossRef] [PubMed]

119. Li, Q.; Wang, B.C.; Xu, Y.; Zhu, Y.X. Systematic studies of $12 \mathrm{~S}$ seed storage protein accumulation and degradation patterns during Arabidopsis seed maturation and early seedling germination stages. J. Biochem. Mol. Biol. 2007, 40, 373-381. [CrossRef] [PubMed]

120. Wu, L.; Ge, Q.; Zhang, J.; Zhou, J.; Xu, J. Proteomic analysis of Cd-responsive proteins in Solanum torvum. Plant Mol. Biol. Rep. 2013, 31, 485-491. [CrossRef]

121. Ahsan, N.; Lee, D.G.; Alam, I.; Kim, P.J.; Lee, J.J.; Ahn, Y.O.; Kwak, S.S.; Lee, I.J.; Bahk, J.D.; Kang, K.Y.; et al. Comparative proteomic study of arsenic-induced differentially expressed proteins in rice roots reveals glutathione plays a central role during As stress. Proteomics 2008, 8, 3561-3576. [CrossRef] [PubMed]

122. Aloui, A.; Recorbet, G.; Gollotte, A.; Robert, F.; Valot, B.; Gianinazzi-Pearson, V.; Aschi-Smiti, S.; Dumas-Gaudot, E. On the mechanisms of cadmium stress alleviation in Medicago truncatula by arbuscular mycorrhizal symbiosis: A root proteomic study. Proteomics 2009, 9, 420-433. [CrossRef] [PubMed]

123. Yang, Y.; Li, X.; Yang, S.; Zhou, Y.; Dong, C.; Ren, J.; Sun, X.; Yang, Y. Comparative physiological and proteomic analysis reveals the leaf response to cadmium-induced stress in poplar (Populus yunnanensis). PLOS ONE 2015, 10, e0137396. [CrossRef]

124. Naka, Y.; Watanabe, K.; Sagor, G.H.M.; Niitsu, M.; Pillai, M.A.; Kusano, T.; Takahashi, Y. Quantitative analysis of plant polyamines including thermospermine during growth and salinity stress. Plant Physiol. Biochem. 2010, 48, 527-533. [CrossRef]

125. Brumbarova, T.; Matros, A.; Mock, H.P.; Bauer, P. A proteomic study showing differential regulation of stress, redox regulation and peroxidase proteins by iron supply and the transcription factor FER. Plant J. 2008, 54, 321-334. [CrossRef]

126. Kim, Y.K.; Lee, M.Y. Proteomic analysis of differentially expressed proteins of rice in response to cadmium. J. Korean Soc. App.l Biol. Chem. 2009, 52, 428-436. [CrossRef]

(C) 2019 by the authors. Licensee MDPI, Basel, Switzerland. This article is an open access article distributed under the terms and conditions of the Creative Commons Attribution (CC BY) license (http://creativecommons.org/licenses/by/4.0/). 